\title{
MINERALOGIA E GRANULOMETRIA DOS LATOSSOLOS DA BACIA DO RIBEIRÃO DO LOBO (BROTAS, ITIRAPINA - SP)
}

\author{
CELSO AUGUSTO CLEMENTE
}

Orientador: Prof. Dr. IBRAHIM OCTAVIÓ ABRAHĀO

Dissertação apresentada à Escola Superior de Agricultura "Luiz de Queiroz", da Universidade de São Paulo, para obtenção do título de Mestre em Solos e Nutrição de Plantas.

PIRACICABA

Estado de São Paulo - Brasil

Maio - 1982 
i .

A memōria de minha avō,

à mi.nha esposa Sueli, aos meus filhos

Gustavo e Ana Carolina

Dedico.

Aos meus pais e irmãos, Ofereço. 


\section{AGRADEC IMENTOS}

Ao Professor Dr. Ibrahim Octavio Abrahão, pela orientação e apoio.

Ao Professor Dr. Arary Marconi, pelas sugestões e colaborações prestadas.

Ao Professor Dr. Antonio Carlos Teixeira Mendes, pela concessão do laboratōrio onde foi realizada boa parte da pesqui sa.

Ao Professor Dr. Octavio Freire, pela dedicação e auxīlio nos trabalhos de campo.

Ao Professor Dr. Zilmar Ziller Marcos, pelo "Summary".

A Fundação Faculdade de Agronomia "Luiz Meneghel" e à Fundação Universidade Estadual de Londrina pelas condições oferecidas.

Ao Departamento de Solos, Geologia e Fertilizantes da Escola Superior de Agricultura "Luiz de Queiroz", pela oportuni dade oferecida.

A CAPES, pelo apoio durante boa parte do curso de pósgraduação.

Aos funcionārios do Departamento de Solos, Geologia e Fertilizantes: Sr. Roberto Forti, pelo acompanhamento e coleta de amostras nos trabalhos de campo e à Sra. Nelci Teixeira Maniero pelos serviços datilogrāficos.

E a todos que, direta ou indiretamente colaboraram para a realização deste trabalho. 


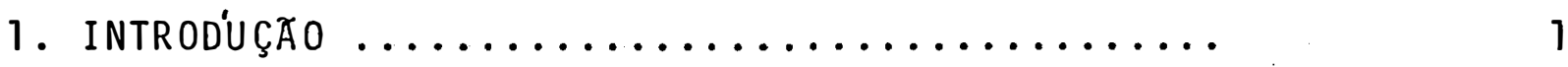

2. REVISATO DE LITERATURA $\ldots \ldots \ldots \ldots \ldots \ldots \ldots \ldots \ldots \ldots$

2.1. Considerações gerais ................ 3

2.2. Preparo de amostras ............... 4

2.2.1. Eliminação da matéria orgânica e dos óxidos de ferro livre ........

2.2.2. Anālise mecânica dos solos .......

2.2.3. Separação da fração leve e pesada.

2.2.4. Escolha da fração areia para estudo $\ldots \ldots \ldots \ldots \ldots \ldots \ldots \ldots \ldots \ldots \ldots$

2.2.5. Nūmeros de grãós e contagem .....

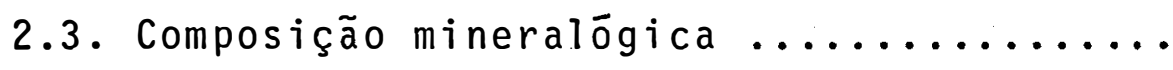

2.4. Arredondamento $\ldots \ldots \ldots \ldots \ldots \ldots \ldots$

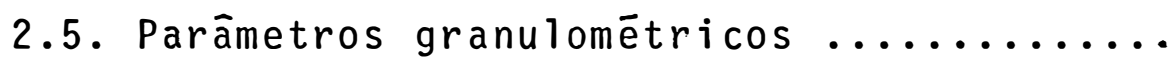

2.5.1. Medida de tendência central .....

2.5.2. Grau de dispersão ou graus de sele ção $\ldots \ldots \ldots \ldots \ldots \ldots \ldots \ldots \ldots \ldots$ 
iv.

Pāgina

2.5.4. Medidas de curtose (grau de agudez

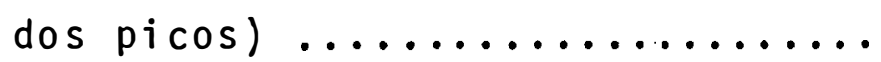

2.5.5. Considerações sobre os parâmetros estatísticos $\ldots \ldots \ldots \ldots \ldots \ldots \ldots$

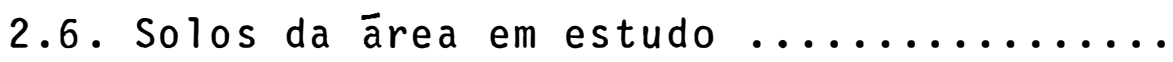

3. CARACTERISTICAS GERAIS DA AREA ........... 27

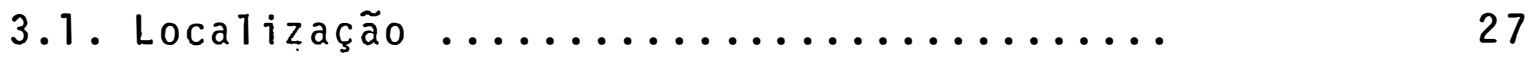

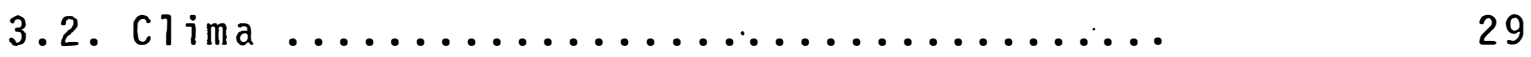

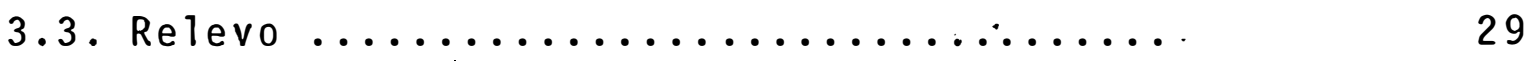

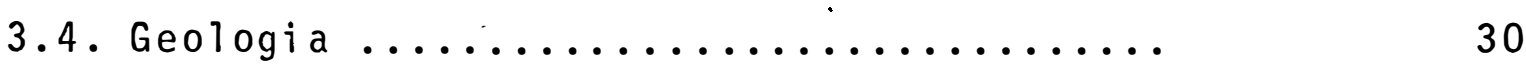

4. MATERIAIS $\ldots \ldots \ldots \ldots \ldots \ldots \ldots \ldots \ldots \ldots \ldots \ldots \ldots \ldots \ldots \ldots \ldots$

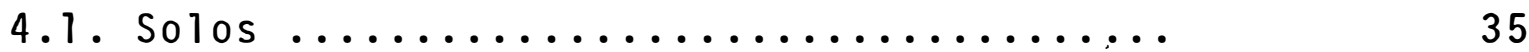

4.2. Instrumental $\ldots \ldots \ldots \ldots \ldots \ldots \ldots \ldots \ldots \ldots \ldots \ldots$

4.2.1. Peneiras ................. 48

4.2.2. Microscópio ............... 48

4.2.3. Centrīfuga ............... 48

5. METODO $\ldots \ldots \ldots \ldots \ldots \ldots \ldots \ldots \ldots \ldots \ldots \ldots \ldots \ldots \ldots \ldots \ldots$

5.1. Amostragem ..................... 49

5.2. Anālise granulomētrica .............. 49

5.3. Preparo das amostras ................ 50

5.3.1. Separação da fração areia total ... 50

5.3.2. Eliminação da matēria orgânica e dos óxidos de ferro livres ....... 50

5.3.3. Separação da fração leve e pesada 50 
5.4. Anālise minerălögica ............... 51

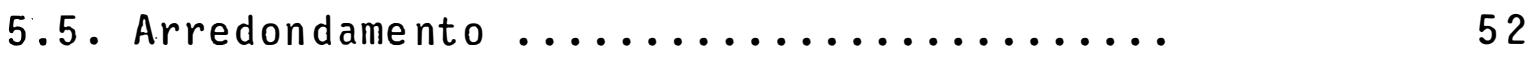

5.6. Anāilise estatistica ................. 52

6. RESULTADOS E DISCUSSAO ................... 53

6.1. Anāilise granulomētrica .............. 53

6.1 .1 . Diâmetro médio $\left(M_{2}\right) \ldots \ldots \ldots \ldots \ldots$

6.1.2. Grau de seleção $\left(\Gamma_{I}\right) \ldots \ldots \ldots \ldots \ldots$

6.1.3. Grau de assimetria $\left(S_{K_{I}}\right) \ldots \ldots \ldots: 60$

6.1 .4 . Curtose $\left(k_{G}\right) \ldots \ldots \ldots \ldots \ldots \ldots$ ?

6.1 .5 . Considerações gerais ............ 62

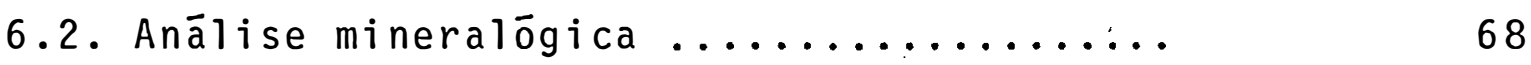

6.2.1. Descrição dos minerais ......... 68

6.2.2. Perfil Pr .................. 70

6.2 .3$. Perfil P2 ................ 73

6.2.4. Perfil P3 .................... 76

$6.2 .5:$ Perfil P4 ................. 80

6.2.6. Considerações gerais ............ 82

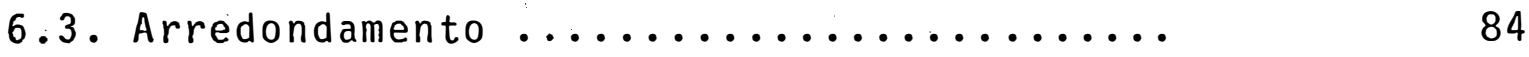

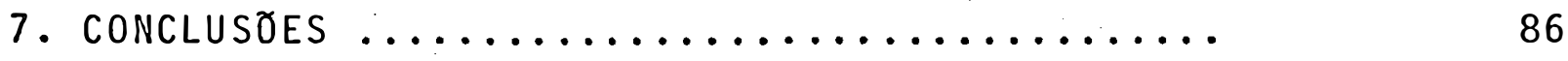

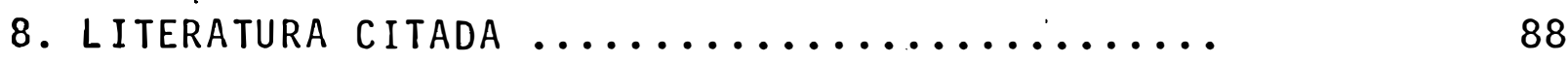


1 - Anālise granulométrica dos perfis P1 e P2.

2 - Anālise granulométrica dos perfis P3 e P4.

3 - Granulometria da fração areia recalculada a

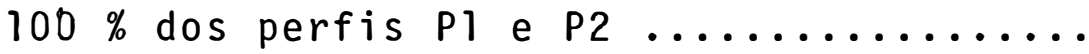

4 Granulometria da fração areia recalculada a

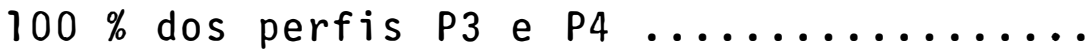

5 Valores dos parāmetros estatísticos, calculados segundo FOLK e WARD (1957) utilizando a escala $\emptyset \ldots \ldots \ldots \ldots \ldots \ldots \ldots \ldots \ldots$

6 - Porcentagem de minerais leves e pesados da fração areia muito fina do Pl ............

7 - Frequēncia dos minerais pesados da fração.

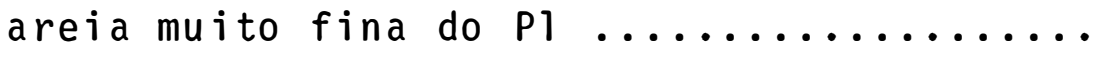

8 - Porcentagem dos minerais pesados do PI (os minerais transparentes estão recalculados

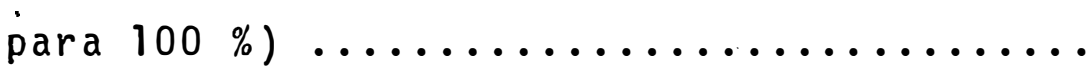

9 - Porcentagem de minerais leves e pesados da fração areia muito fina do $P 2 \ldots \ldots \ldots \ldots \ldots$ 
vii .

Pāgina

10 - Frequência dos minerais pesados da fração

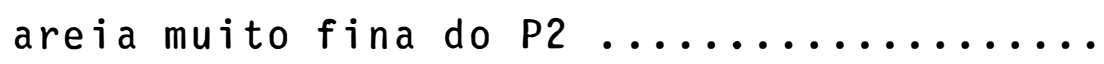

11 - Porcentagem dos minerais pesados do P2 los minerais transparentes somam $100 \%$ ) ......

12 - Porcentagem de minerais leves e pesados da fração areia muito fina do $P 3 \ldots \ldots \ldots \ldots$

13 - Frequência dos minerais pesados da fração areia muito fina do $P 3 . . . \ldots . . . \ldots . .$.

14 - Porcentagem dos minerais pesados do P3 los minerais transparentes somam $100 \%$ ) ......

15 - Porcentagem de minerais leves e pesados da fração areia muito fina do P4.............

16 - Frequência dos minerais pesados dà fração

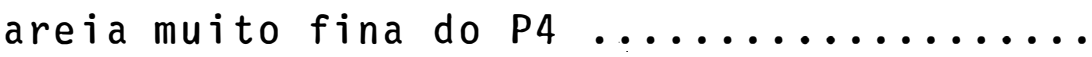

17 - Porcentagem dos minerais pesados do P4 (os minerais transparentes somam $100 \%$ ) ......

18 - Arredondamento dos grãos de quartzo da fração areia muito fina dos perfis 
viii.

LISTA DE FIGURAS

Pāgina

1 - Localização da ārea estudada .............

2 - Mapa geológico da Bacia do Ribeirão do Lobo IBRASIL - D.N.P.M., 1979 ).............

3 - Mapa de solos da Bacia do Ribeirão do Lobo

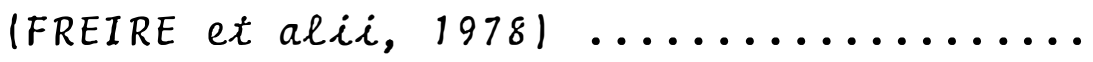

4 - Mapa da ārea de estudo com a localização dos Perfis (Projeto Sapucaî, 1979 - Folha Campi

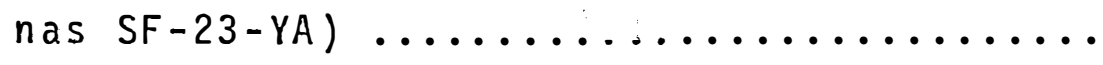

5 Curvas acumulativas dos horizontes do Perfil P1 $\ldots \ldots \ldots \ldots \ldots \ldots \ldots \ldots \ldots \ldots \ldots \ldots \ldots \ldots \ldots \ldots$

6 Curvas acumulativas dos horizontes do Perfil P2

7 Curvas acumulativas dos horizontes do Perfil P3

8 - Curvas acumulativas dos horizontes do Perfil P4 $\ldots \ldots \ldots \ldots \ldots \ldots \ldots \ldots \ldots \ldots \ldots \ldots \ldots \ldots$

9 - Curvas de frequência de distribuição granulomētrica dos perfis 
10 Porcentagem de Zirconita, Turmalina e Es -

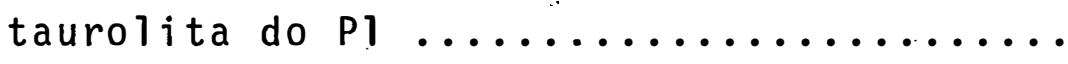

11 Relação Zirconita/Turmalina do P1........

12 Porcentagem de Zirconita, Turmalina e Es-

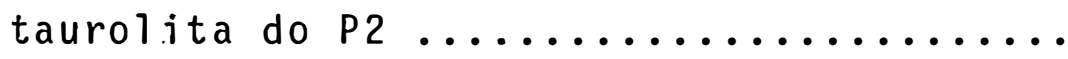

13 Relação Zirconita/Turmalina do P2 ........

14 Porcentagem de Zirconita, Turmalina e Es-

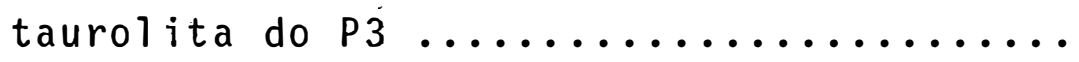

15 Relação Zirconita/Turmalina do P3 ........

16 Porcentagem de minerais opacos e transpa rentes em profundidade dos perfis ........ 
MINERALOGIA E GRANULOMETRIA DOS LATOSSOLOS DA BACIA DO RIBEIRAO DO LOBO (BROTAS, ITIRAPINA - SP).

Candidato: Celso Augusto Clemente Orientador: Prof. Ibrahim Octavio Abrahão

RESUMO

Os perfis de Latossolos da Bacia do Ribeirão do Lobo, região de São Carlos, Brotas e. Itirapina, SP, foram amostrados e estudados atravēs de anālise granulomētrica, empregando-se os parâmetros estatísticos propostos por FOLK e WARD (1957), anālise mineralógica do resîduo pesado da fração areia muito fina e do arredondamento desta fração de areia.

Os objetivos principais do trabalho são a caracterização do material de origem e a uniformidade dos solos, el $\underline{u}$ cidação de sua gênese e evolução e a confirmação ou informação da semelhança entre perfis constatada previamente pela morfologia.

Confirma-se a hipōtese inicialmente estabelecida: os parâmetros granulométricos e mineralógicos permitem distin guir duas classes, entre os solos estudados. A primeira reune 
trēs solos (Latossol Vermelho-Amarelo Distrōfico ālico A fraco textura arenosa, Latossol Vermelho Escuro Distrōfico ālico A fraco textura arenosa e Latossol Vermelho Escuro Distrōfico ālico A moderado textura mēdia) com predominante contribuição da Formação Botucatu e nos quais se identificaram descontinuidades litológicas. A segunda classe é representada por um solo totalmente homogêneo (Latossol Vermelho-Amarelo Distrofico āli co A fraco textura média), que recebeu contribuição associada das Formações Botucatu e Serra Geral. 
$x i j$.

MINERALOGY AND PARTICLE SIZE DISTRIBUTION OF LATOSOLS OCCURRING IN THE LOBO CREEK BASIN (BROTAS, ITIRAPINA - SP)

Candidate: Celso Augusto Clemente

Adviser: Prof. Ibrahim Octavio Abrahão

SUMMARY

Profiles of the latosols occurring in the Lobo

- Creek Basin, São Carlos, Brotas and Itirapina regions, SP, were sampled and studied by means of the following analysis:particle size distribution using the statistical parameters proposed by FOLK and WARD (1957); mineralogy very fine of sand fraction hea vy residue and roundness of same sand fraction.

The main objectives of this work were the charac terization of parent material and uniformity of soils, explana- tion of its genesis and evolution and the confirmation or infor mation regarding profile similarities previously observed in soil morphological studies.

The hypothesis set forth was confirmed: the granulometric and mineralogical parameters allowed the distinction of two classes among the soils studied. The first comprises 
xiii.

three soils (Red-Yellow Latosol, distrophic alic weak A sandy texture, Dark-Red Latosol distrophic alic weak A sandy texture and Dark-Red Latosol distrophic alic moderate A medium texture) with a dominating contribution of Botucatu Formation and in which lithological discontinuity were identified. The second class is represented by a soil totally homogeneous (Red-Yellow Latosol distrophic alic weak A medium texture), derived from a combination of Botucatu and Serra Geral Formation materials. 
1. INTRODU,ÇAO

Os Latossolos da Bacia do Ribeirão do Lobo, que - se localiza nos municípios de Brotas, Itirapina e São Carlos no Estado de São Paulo, foram levantados e classificados a nível de grande grupo pela COMISSAO DE SOLOS DO CNEPA (1960). Recente mente, FREIRE et alii (1978) estudaram física, química e morfologicamente esses solos e completaram fazendo um levantamento semi-detalhado, classificando os solos a nível de sub-grupo.

No presente trabalho, as quatro unidades de Lato $\underline{s}$ solos identificadas foram estudadas do ponto de vista das características mineralógicas e granulométricas da fração areia muito fina, num total de 20 horizontes. Adotase, portanto, a hipótese bāsica de que os parâmetros mineralógicos e granulométricos constituem-se em dados auxiliares importantes e às vezes decisivos na classificação e caracterização de solos. Paralelamente, estas análises visaram, ainda, à obtenção de informações 
que possam contribuir para elucidação de sua gênese e evolução, bem como a confirmação ou infirmação da aparente uniformidade morfológica evidenciada pelá classificação de FREIRE (1978), ou seja, se os perfis de uma mesma unidade sao mineraló gica e granulometricamente equivalentes ou não. 


\section{REVISAO DE LITERATURA}

\subsection{Considerações gerais}

0 emprego da composição mineralógica dos parâmetros granulométricos começou a ser reconhecido como de importān cia em estudos pedogenéticos, antes ainda do inî́cio deste sécu10, quando Thdrach, em 1880 (in SINDOWSKI, 1949) inspirou cientistas alemães a adaptarem a solos seu método de identificação de minerais na Alemanha. Mas, foi no inīcio deste século que a mineralogia começou a evoluir e a ser mais empregada, quando ho landeses e americanos, particularmente Mc Caughey e Fry (1913), deram detalhes dos métodos usados em estudo mineralógico de sedimentos consolidados e mostraram que esses métodos também podiam ser aplicados a estudos de solos (HASEMAN e MARSHALL, 1945). Entretanto, somente na década de 30 é que o método tomou impulso e evoluiu, novamente através de contribuição de Mc Caughey e Fry em 1917 (in JEFFRIES, 1937). Esses autores identificando 34 
minerais em solos dos Estados Unidos, concluiram que varia a composição mineralógica, em função da região de ocorrência dos solos. A partir de então, os trabalhos se avolumaram, existindo, atualmente uma extensa literatura sobre o assunto, abordan do os principais aspectos envolvidos no problema. Dessa forma, apresenta-se neste capitulo um apanhado geral sobre as principais questões envolvidas no preparo de amostras e na aplicação do arredondamento, da composição mineralógica e dos parâmetros granulomētricos a sedimentos e solos.

\subsection{Preparo de amostras.}

0 desenvolvimento dos trabalhos sobre mineralogia de solos conduziu ao estabelecimento de técnicas até certo ponto padronizadas para o preparo de amostras. Atualmente, estão consagradas e em uso rotineiro:

2.2.1. Eliminação da matēria orgānica e dos óxidos de ferro livre

Na eliminação da matēria orgânica os métodos mais usados são o de JEFFRIES e JACKSON (1949) com o uso de pe rōxido de hidrogēnio e o de JACKSON (1956) com o perōxido de hidrogēnio a 30 \% em meio ligeiramente ācido e em banho maria.

Para remoção de óxido de ferro livre, AGUILERA

e JACKSON (1953) introduziram o método usando hipossulfeto e citrato de sódio, posteriormente JACKSON (1956) aperfeiçoa e apre 
ta o mētodo do ditionito-citrato-bicarbonato de sōdio, o qual tem se mostrado menos prejudicial aos minerais.

\subsubsection{Anālise mecānica dos solos}

Para este tipo de investigação è mais indicada a escala da U.S. Bureau of Soils na qual as seguintes classes são obtidas: areia muito grossa $(2-1 \mathrm{~mm})$; areia grossa $(1-0,5 \mathrm{~mm})$; areia média $(0,5-0,25 \mathrm{~mm})$; areia fina $(0,25-0,10 \mathrm{~mm})$; areia mu $i$ to fina $(0,10-0,05 \mathrm{~mm}) ; \operatorname{silte}(0,05-0,002 \mathrm{~mm}) ; \operatorname{argila}(0,002$

- $\mathrm{mm})$. A parte superior da escala da U.S. Bureau of Soils tem fra ções granulomētricas semelhantes àquelas da escala Wentworth e mesmo a areia fina e silte aproximam-se dela, provavelmente dentro da margem de erro causada por tolerāncia da malha. Isto significa que os solos podem ser examinados mecanicamente como um material sedimentar, e isto facilita a interpretação dos resultados das curvas acumulativas e erros estatisticos.

\subsubsection{Separação da fração leve e pesada}

os processos e técnicas para a separação das frä ções e obtenção do resíduo pesado, envolvem as prōprias densida des dos minerais. KRUMBEIN e PETTIJOHN (1938) apresentam e discutem vārias técnicas de obtenção do resíduo pesado, ressaltando o emprego de Tíquido pesado. Dentre esses, discorrem sobre 
as vantagens do uso do bromofórmio, citando schoroeder e Van der Kolk como os primeiros a utilizarem-se dele, em 1895.A par tir de então, grande nūmero de pesquisadores optou pelo uso do bromofórmio, dada as vantagens e eficiências que oferece. Dentre eles, citam-se JEFFRIES e JACKSON (1949), MARCONI (1969), LOBO (1971), BAHIA (1973), WINKELJOHAN (1975), MARCONI \& ABRAHÃO (1977) e KÜPPER (1978).

2.2.4. Escolha da fração areia para estudo

A fração areia mais indicadá para estudo minera lögico tem sido motivo de controvērsias, sendo muitos os autores a fazerem recomendações nesse sentido. COGEN (1935) acha necessārio o estudo de todas as frações de areia, assinalando, porem, que sedimentos assim estudados só podem ser comparados com aqueles que sofrem o mesmo tratamento. MARSHALL e JEFFRIES (1945) e HASEMAN e MARSHALL (1945) concluiram em seus trabalhos que em cada classe textural devem ser esperadas diferentes associações mineralógicas, confirmando o que foi dito por cogen. Entretanto, autores, como HENDRICK e NEWLANDS (1923), JEFFRIES (1937) e CARROL (1938) sugerem o estudo apenas das frações mais finas da areia, no que são confirmados por DOEGLAS (1939) que recomenda o exame de apenas uma fração de areia. Essa orientação tem sido seguida por autores nacionais como MARCONI (1969), LOBO (1971), BAHIA (1973), MARCONI E ABRAHAO (1977); GALHEGO 
(1977) entre outros, que utilizaram, ou a fração areia fina ou a fração areia muito fina, como representativa da moda do sedi mento.

Contudo, RUBEY (1933) contestava a validade do uso da moda, como a mais indicada para estudo do resíduo pesado do sedimento. Observava esse autor, com certa razão, que não pode ser desprezada a densidade dos minerais, que faz com que sejam depositados, juntamente com minerais leves (quartzo e feldspatos), os minerais pesados de tamanho menor. Nesse caso, para estudo do resīduo pesado de um sedimento, é recomendā vel a utilização da fração ganulométrica mais fina justaposta. a fração modal, orientação esta seguida neste trabalho.

2.2.5. Nümeros de grãos e contagem

Quanto ao nūmero de grãos necessārios para significar uma amostragem boa, não existe concordāncia entre os autores. Os valores indicam desde um nümero de 100 grānulos (Grahan,in KRUMBEIN e PETTIJOHN, 1938) até a totalidade' dos grânulos existentes na lâmina (JACKSON, 1956). DOROTHY CARROL (1938) e KRUMBEIN e PETTIJOHN (1938) no entanto, sugerem que a contagem de 300 grānulos é suficiente para a caracterização de uma amostra. Entre os autores nacionais tambēm não hā concor dância quanto aos valores, encontrando-se 300 grânulos para 
BONI (1976) e GALHEGO (1977), entre 160 a 950 para WINKELJOHAN (1975), 170 a 650 para BAHIA (1973), 500 a 1250 para MARCONI (1969), 300 a 600 para $\angle O B O(1971)$, em torno de 200 para KüpPER (1978) e a totalidade dos minerais existentes na lâmina para RODRIGUES $(1979)$.

\subsection{Composição mineralógica}

0 es.tudo da composição mineralógica, especial mente dos minerais pesados, recebe especial atenção em livros textos publicados por KRUMBEIN e PETTIJOHN. (1938), KRUMBEIN e SLOSS (1969), MILNER (1962) e BREWER (1964).

No Brasil, CAMARGO e VAGELER (1937) situam-se entre os primeiros a reconhecerem a importância da mineralogia no estudo de solos, ao afirmamrem que a formação de muitos solos tropicais só seria compreensível após o estudo mineralógico da rocha-matriz.

Segundo PETTIJOHN (1949) existe uma estreita re lação entre minerais pesados e proveniēncia. Baseando-se, então, nesta premissa formulou as seguintes relações: 
Mineral pesado.

Turmalina

Turmalina arredonda.

Estaurolita

Zirconita

(euhedral)

Zirconita

(arredondada)

Rutilo
Proveniência:

Rochas Pegmatiticas

Sedimentos retrabaIhado

Metamorfismo de alto grau, xistos e gnaisses

Rochas ígneas ācidas e intermediārias

Sedimentos retrabaIhados

Rochas ĩgneas bāsitcas e sedimentos re trabalhadas)
Minerais Associados

Rutilo e Zirconita

Rutilo, Zirconita arredondadas

Moscovita e biotita, epídoto, cianita,an daluzita, magnetita

Titanita, magnetita apatita, biotita, moscovita

Rutilo, turmalina (arredondada)

Ilmenita e magnetita

A interpretação completa dos dados de minerais, conclui o autor, necessita da consideração das proporções rela tivas de cada grupo de minerais, do grau de arredondamento dos graos e de outros fatores. 
Muitos autores formularam listas de minerais segundo sua ordem de resistência ao intemperismo para equacionar os processos pelos quais passam os sedimentos atē atingirem um estado de completa estabilidade química, atribuindo-se a isto a designação de maturidade mineralógica. Consideram que este fenō meno está ligado à ordem de persistência dos minerais. Assim, por exemplo, a presença de anfibólios e piroxênios nos sedimentos indicam derivação direta da rocha formadora, mas sua ausenncia não indica condições de longo transporte. Poderia estar ausente na rocha matriz ou sugerir intemperismo rigoroso ou ainda, retrabalhamento dos sedimentos. Uma das principais escalas de estabilidade ou resistência mineralógica é a de SINDOWSKY (in PETTIJOHN, 1957), que apresenta os seguintes minerais, enumerados em ordem decrescente de resistência: 1 - Zircão, 2 - Ruti10, 3 - Turmalina, 4 - Estaurolita, 5 - Cianita, 6 - Hornblenda, 7 - Granada, 8 - Augita, 9 - Apatita e 10 - 01 ivina.

Entretanto, CADY (in BLACK, 1965) advertiu que listas de minerais arranjados segundo sua ordem de resistência são dados em muitas publicações, mas, como todas as generalizaçoes, devem ser usadas com cuidado.

RRYNINE (1946), estudando turmalinas salientou que há provavelmente muito mais turmalinas em sedimentos (solos) do que comumente se costuma descrever, porque algumas varieda - 
des podem ser confundidas com outros minerais. Neste trabalho,o autor reconheceu treze sub-espēcies desse mineral, tendo descri to cinco grupos especiais: (1) turmalina granitica; (2) turmali na pegmatítica; (3) turmalina de metamorfismo de baixo grau; (4) turmalina sedimentar autígena e (5) turmalina de sedimentos retrabalhados. Cada tipo tem propriedade ópticas e morfológi cas diagnósticas e que permitem reconhecer e interpretar corretamente a proveniência do sediménto.

A importância da aplicação do estudo da mineralo gia da fração grosseira dos solos, tendo como principal objetivo a complementação das condições genēticas destes, pode ser constatada na afirmação de BREWER (1964, in LOBO, 1971). "Talvez a mais importante aplicação da anālise mineralógica das frações grosseiras do solo, ē a de constatar ou não a uniformidade do perfil do solo em relação a rocha, ou em relação aos próprios horizontes". Prosseguindo, este autor observa que "o melhor método para tal estudo, o mais dĩgno de confiança, é aquele basea do na comparação dos minerais mais resistentes tais como zirconita e turmalina". Segundo BREWER (1964), ainda, a razão entre dois minerais resistentes deverā ser tanto mais constante com a profundidade, quanto maior for a uniformidade do material de or $\underline{i}$ gem. Para um material de origem uniforme, a curva de variação da relação zirconita/turmalina, em face a profundidade do per fil, deverá ser suave, sem pontos de inflexão. 
BEAVERS (1960), utilizando-se de espectrografia dos raios-X como meio de identificação de zirconita em solos: constatou a presença de descontinuidades litológicas, conseguin do ainda com os dados obtidos caracterizar a proveniencia dos solos estudados.

No Brasil, o estudo de minerais pesados é muito frequente para rochas sedimentares, porém sobre mineralogia da fração grósseira dos solos é relativamente pequeno o nūmero de trabalhos realizados. Devemos salientar, também, que a escolha dos minerais-indice para verificação de descontinuidade litoló gica é muito diversificada, variando de autor para autor.

MARCONI (1969), estudando solos situados sobre a Formação Botucatu, no município de Piracicaba,SP, com base na composição mineralógica, divide-os em dois grupos: um com predominância de estaurolita e outro com predominância de minerais opacos e relativamente baixa ocorréncia de estaurolita: Concluị,ainda, que os valores altos encontrados para, arredonda mento indicam terem os minerais participado de mais de um ciclo de sedimentação, sofrendo removimentação de sedimentos mais antigos que o arenito Botucatu,originados de rochas metamórficas e eruptivas.

LOBO (1971), em solos do municipio de Piracicaba,SP,com base na variação Z/T, revela a presença de desconti nuidades litológicas em todos os solos estudados, embora nem sempre associadas à presenca de linhac do nodrac 
Com o intuito de identificar o material de ori gem e possĩvel ocorrência de descontinuidade litológica, BAHIA (1973) estudou dois perfis de Latossol Vermelho Amarelo fase are nosa da Série Morro Azur, de ocorrência no municĩpio de Iracemā polis, SP. Após anālise dos minerais leves através do arredonda mento dos grãos de quartzo e da composição mineralógica qualita tiva e quantitativa da fração pesada pelos métodos petrogrāfi cos padrões, o autor concluiu que os perfis de solo da série Morro Azul são provavelmente derivados de sedimentos retrabalha dos da Formação Corumbataî e que nos dois perfis estudados as - relações $Z / T+R$ apresentam dois pontos de mínimo, indicando descontinuidades litológicas, relacionadas ou não com linha de se $\underline{i}$ xos. Acrescenta, também, que devido a predominância de zirconita, nos solos estudados, o ambiente de formação seria diferente daquele atribuido por Ranzani et alii, 1968 (in BAHIA, 1973 ) co mo de origem eólica.

Pela aplicâção de dados de frequência numérica dos minerais transparentes estáveis (zircorita e turmalina) e semi-estáveis (éstaurolita) em estudos dos arenitos da Formação Furnas, Rio Bonito e Botucatu, SUGuTo et alii (1971), atesta ram e confirmaram a hipōtese inicial da existência de retraba Ihamento sucessivos na sedimentação desses arenitos. 
WINKELJOHANN (1975), atravēs de estudo das varia ções no perfil das relações areia muito fina/areia grossa e das relações $Z / R, Z / R+T$ e $Z / R+Z$ da areia muito fina, da Série Guamium (Latossol Vermelho-Amarelo orto) conclui que estes solos são provenientes de sedimentos retrabalhados e que apresentam descontinuidades litológicas indicados por pontos de mínimo na relação amf/ag e confirmados pelos índices $Z / R, Z / R+T$ e $Z / R+Z$.

DEMATTE (1978), utilizando a mesma tēcnica de Beavers (1960) e contribuindo com os trabalhos qlie preconizam as relações entre minerais pesados na avaliação da homogeneidade do material de origem do solo, conclui que o uso da zirconita da fração areia dos solos é um bom critério. Entretanto, aconse lha um maior estudo da variabilidade e da distribuição desse mi neral em um número grande de vārios tipos de solos, situados em diversos climas e provenientes de diferentes materiais de origem. Salienta, ainda, que na falta de dados já citados e de evi dências morfológicas de descontinuidade, é aconselhāvel utili zar uma diferença superior a $100 \%$ no teor de zirconita entre horizontes como critério de caracterização de descontinuidade.

Inūmeros outros pesquisadores contemporāneos ser vem-se, ainda de sugestões e discussões de seus antecessores, confirmando a importância do estudo da mineralogia da fração grosseira dos sedimentos para verificação de gênese do material 
de origem, caracterização de descontinuidade litológica e prove niência dos sedimentos (ou solos). Dentre estes autores, in cluem-se BONI (1976), SUGUIO (1976), GALHEGO (1977), MARCONI e ABRAHAO (1977), KÜPPER (1978) e RODRIGUES (1979).

\subsection{Arredondamento.}

A maioria dos autores, entre eles suguio (1973), considera 0 arredondamento um parāmetro que mostra a maior ou menor angulosidade das arestas e vértices de um grānulo mineral. Este estudo adquire importância na medida em que revela se 0 ma terial analisado guarda ou não traços da sua forma original, ex trapolando conclusões sobre a constituição do material de ori gem e a distância que o material analisado percorreu para adqui rir uma determinada forma.

o estudo inicial da relação entre o arredondamen to de grânulos de minerais e seu transporte foi primeiramente realizado por Doubrēe, em 1879 (PETTIJOHN, 1957). Wadell (MARCONI, 1969l. estuda, pormenorizadamente, a forma dos grânulos de sedimentos e define esfericidade e arredondamento, mostrando que são variāveis independentes. Entretanto, a fim de evitar as dificuldades que os métodos preconizados por Wadell apresentam, Krumbein e Sloss (in, BREWER, 1964) apresentam uma carta para avaliação visual de arredondamento e esfericidade. PETTIJOHN 
(1957) apresenta uma classificação para arredondamento baseada nos estudos de Wadell, aceita e usada mundialmente: grãnulos angulares $(0,00$ a 0,15$)$; subangulares $(0,15$ a 0,25$)$; subarredon dados $(0,25$ a 0,40$)$; arredondados $(0,40$ a 0,60$)$; bem arredonda$\operatorname{dos}(0,60$ a 1,00$)$.

Com o intuito de dimensionar o nūmero de grânu los a serém contados em cada lâmina para avaliação precisa de a $\underline{r}$ redondamento ou de esfericidade de partículas e suas variações com relação aos observadores ROSENFELD et alii (1953) após estú do estatistico, concluiram que cinquenta ou mais partículas podem ser consideradas representativas porque os erros de estimação são plenamente compensados.

Jā MARCONI et alii (19.70), em um minucioso estudo estatístico, concluem que a contagem de 25 grânulos em cada lâmina, é suficiente para avaliação precisa do arredondamento.

Um grande nümero de autores nacionais utilizou da carta de comparação visual de KRUMBEIN e SLOSS, obtendo re sultados conclusivos em seus trabalhos. Então esses autores, MARCONI (1969), MARCONI et alii (1970), BAHIA (1973), KUlPPER

(1978) e RODRIGUES (1979) aplicaram o estudo de arredondamento a solos, enquanto PARAGUASSū (1970/1971), BJSIO et alii (1978) e WERNICK et alii (1972) usaram esse parâmetro no estudo de ou tros sedimentos. 


\subsection{Parāmetros granulomētricos}

0 emprego de parāmetros granulomētricos consti tui-se em importante método auxiliar no estudo de solos, princi palmente com relação à determinação do material de origem, uniformidade do solo e processo de transporte dos sedimentos origi nados.

Segundo ALTAFIN (1977), acredita-se que amostras de grānulos da fração areia, podem dar uma idéia mais aproximada do sedimento original e da uniformidade dos horizontes no que diz respeito à sua curva granulomētrica. Para esta afirma ção o autor baseia-se na premissa, de que a fração areia representa maior estabilidade no perfil, ao contrário das frações mais finas que, normalmente, podem se locomover de um horizonte para outro.

A anālise de tamanho e forma dos minerais consti tui-se na metodologia mais empregada, baseando-se, em sua quase tótalidade, em estimativas de parâmetros estatísticos. Métodos e desenvolvimento da aplicação da estatística a sedimentologia são encontrados em KRUMBEIN e PETTIJOHN (1938), BREWER (1964), suguio (1973) entre outros. 
Segundo SUGuio (1973) os coeficientes mais comuns atualmente em uso são calculados com base em dados extraí dos das curvas acumulativas da distribuição de percentagens de peso das diferentes frações dos sedimentos ou solos analisados. Esses coeficientes são geralmente calculados com dados granulo métricos na escala $\emptyset$ de Krumbein e servem para caracterizar a curva quanto a sua tendência central, grau de dispersão, grau de assimetria e grau de agudez dos picos (curtose).

\subsubsection{Medida cie tendência central}

Em sedimentologia, a medida de tendéncia central mais utilizada ē a média aritmética (MZ) que pode ser obtida pe la fórmula de FOLK e WARD (1957)

$$
\frac{916+950+\emptyset 84}{3}
$$

em que $\emptyset$ i indica o valor de $\emptyset$ abaixo do qual existe $i \%$ de grânu los (em peso).

Segundo McCammon (1962) in SUGUio (1973) a fōrmu la fornece um grau de eficiēncia de $88 \%$, o que considera uma estimativa razoável até em curvas não muito assimëtricas.

Recentemente, tem sido tambēm considerado como valor importante a moda, que reflete o valor mais representati- 
vo, mais frequente. E especialmente $\bar{u}$ til no estudo de fontes mistas de material com grande significado genético, conforme cị tações de Curray (1960, in SuguIo 1973), Erezina (1963 in suGUI, 19731 .

\subsubsection{Grau de dispersão ou grau de seleção}

Diversas fōrmulas tem sido empregadas para repre sentar a dispersão dos grânulos no sedimento (ver BREWER, 1964; Suguio, 1973). A mais empregada entre elas, é o coeficiente $\ddot{\Gamma}_{I}$ proposto por FOLK e WARD (1957) pelo simples motivo de ser simplificado e que è dado por:

$$
\Gamma_{\mathrm{I}}=\frac{\emptyset 84-\emptyset 16}{4}+\frac{\emptyset 95-\emptyset 5}{6.6}
$$

Essa fórmula fornece uma estimativa razoável do verdadeiro desvio padrão em curvas não muito assimētricas. [BREWER (1964) e FOLK (1966) fornecem uma comparação de valores estị mados por diferentes fórmulas.

FOLK e WARD (1957) sugerem para $\Gamma_{I}$ os seguintes limites e interpretação: 
20 .

\begin{tabular}{|c|c|c|}
\hline$\Gamma_{I}$ & & g.rau de seleção \\
\hline$<\quad, 0 ; 35$ & $=$ & muito bem selecionado \\
\hline 0,35 a 0,50 & $=$ & bem selecionado \\
\hline 0,50 a 1,00 & $=$ & moderadamente selecionado \\
\hline 1,00 a 2,00 & $=$ & pobremente selecionado \\
\hline 2,00 a 4,00 & $=$ & muito pobremente selecionado \\
\hline$>\quad 4,00$ & $=$ & extremamente mal selecionado \\
\hline
\end{tabular}

Em sedimentologia, o desvio padrão pode indicar a velocidade do agente transportador, a mistura de fontes de material ou a distância do transporte. Mistura de fontes ou de agentes de transporte, variações de velocidade e transporte cur to tendem a fornecer sedimentos de baixo grau de seleção.

\subsubsection{Grau de assimetria}

Segundo Suguio (1973), o grau de assimetria de um sedimento é indicado pelo afastamento do diāmetro médio em relação à mediana.

Em sedimentologia, (ALTAFIN 1977), a assimetria revela discrepâncias em relação a lognormalidade, que podem ser atribuidas a vārias causas: presença de fontes heterogêneas de fornecimento de material, se o agente transportador se mantiver 
constante; diferença de energia do agente transportador, se a fonte for constante e homogênea; distância da fonte. Entretanto, essas diminuições não são totalmente estabelecidas.

Para cālculo de assimetria, existem diversos coe ficientes de determinação, mas em sedimentologia a fórmula mais empregada é a de FOLK e WARD (1957):

$$
S k_{I}=\frac{\emptyset 16+\emptyset 84-2 \emptyset 50}{2(\emptyset 84-\emptyset 16)}+\frac{\emptyset 5+\emptyset 95-2 \emptyset 50}{2(\emptyset 95-\emptyset 5)}
$$

Matematicamente, todos os valores de assimetria desta fórmula estão no intervalo -1 a 1 , mas poucas curvas possuem graus de assimetria fora do interior $-0,8$ e 0,8 . Para cur- vas simétricas o valor esperado é zero. Se os resultados forem positivos, a amostra possuirā uma cauda tendendo para o lado do material mais fino; se os valores forem negativos, a cauda esta rā do lado dos materiais mais grosseiros, demonstrando, assim., que há relação entre a assimetria e a granulometria ou a disper são, FOLK e WARD (1957), SUGUTO (1973).

FOLK e WARD (1957) sugerem uma escala para inter pretação: 


$\begin{array}{rlll}\text { SKI } & & \text { grau de assimetria } \\ -1,00 \text { e }-0,30 & = & \text { muito negativa } \\ -0,30 \text { e }-0,10 & = & \text { negativa } \\ -0,10 \text { e }+0,10 & = & \text { aproximadamente simētrica } \\ +0,10 \text { e }+0,30 & = & \text { positiva } \\ +0,30 \text { e }+1,00 & = & \text { muito positiva. }\end{array}$

2.5.4. Medidas de curtose (grau de agudez dos picos)

Essa medida trata do grau de achatamento dos picos nas curvas de distribuição de frequência. Uma distribuição de pico relativamente alta ao redor da média é chamada leptocúr tica, enquanto que a de tipo achatado é denominada platicúrtica. A distribuição normal, não muito achatada, é denominada mesocūr tica.

Identicamente à assimetria, existem diversas fōr mulas para cālculo de curtose, mas, em sedimentologia, a mais empregada é a de FOLK e (WARD (1957):

$$
K_{G}=\frac{\emptyset 95-\emptyset 5}{2,44(\emptyset 75-\emptyset 25)}
$$

Curvas normais tem valor de $K_{G}=1,00$. Valores menores que 1 indicam curvas platicūrtica e em sedimentologia 
isso normalmente é devido à contribuição de mais de uma moda. $K_{G}=0,6$ indica uma curva bimodal, tipo "sela de cavalo" e curva muito leptocūrticas pode indicar que o sedimento é muito bem selecionado na parte central da distribuição.

FOLK e WARD (1957) propõem para a curtose a seguinte interpretação:

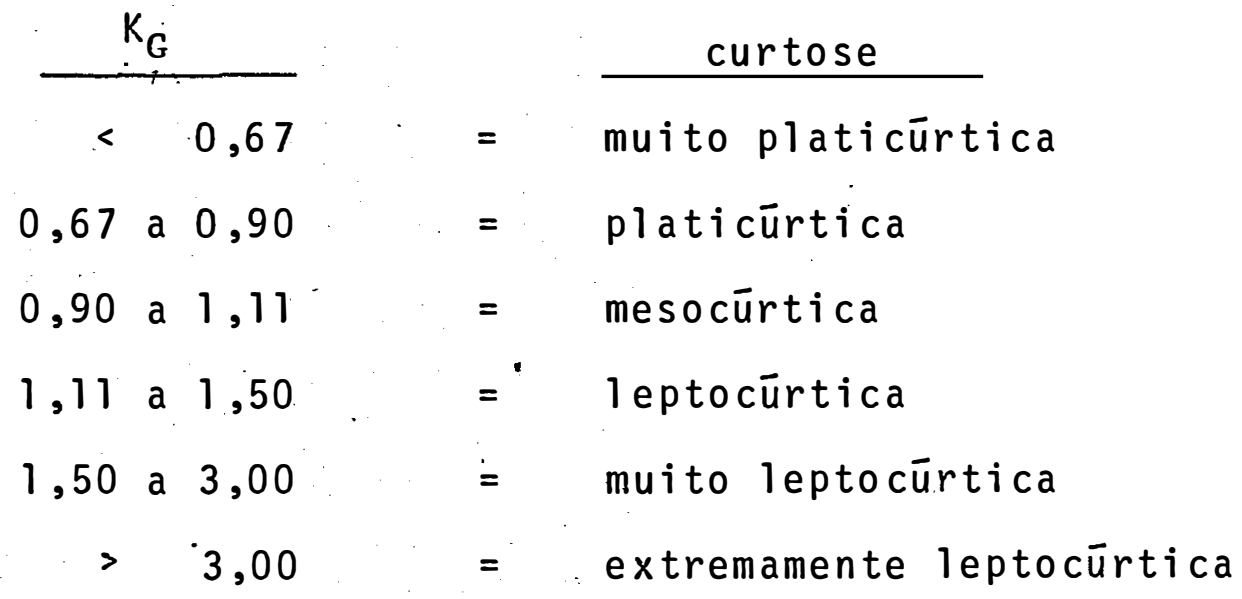

2.5.5. Considerações sobre os parâmetros estatísticos

Diversos autores obtiveram importantes conclusões a partir dos parāmetros estatísticos citados.

BOSIO et alii $(1970 / 1971)$, aliando o estudo de forma e arredondamento aos paràmetros estatísticos acima, no es tudo de sedimentos da Formação Caiuā, chegaram à conclusão que - ambiente de deposição desse arenito é fluvial e não eólico co mo alguns autores afirmam. Notaram, ainda, que a forma e ar- 
redondamento dos grãos são bastante semelhantes aos do Arenito Botucatu, porém com melhor grau de seleção, concluindo haver uma ligação genética entre ambas as Formações, considerando que os sedimentos do Caiuá teriam sido produto de retrabalhamento do Arenito Botucatu.

ALTAFIN (1977) aplicou esses parāmetros estatís ticos aos solos, LE fase arenosa, LVA fase arenosa e Regossol desenvolvidos sobre o Arenito Bauru com o propósito de investi gar as prováveis condições de deposição e uniformidade dos per fis. Comparou a fração maior que $4 \emptyset$ desses solos com os trabaThos de ARID et alii (1975), em frações menores que $4 \emptyset$, concluindo que as frações por ele estudadas são mais estáveis,não se movimentando de um horizonte para outro. Conclui também que os três solos possuem características granulométricas que suge rem que os sedimentos originais tiveram deposição fluvial.

MARCONI e ABRAHAO (1977), utilizaram-se tambēm dos parâmetros granulométricos de FOLK e WARD para estabele cer uniformidade de perfis de solos e ambientes de deposição em solos da Bahia, chegando a concluir que o ambiente de deposição do material de origem dos solos foi o fluvial.

Muitos outros pesquisadores valeram-se desses parāmetros granulométricos, ora isoladamente, ora aliados a da dos de composição mineralógica elou aliảdos a forma e arredon- 
damento de minerais, conseguindo interessantes conclusões. En tre eles incluem-se MARCONI (1969), sUguio (1974), sUguio et alii (1976), BONI (1977), ALOISI et alii (1978), KUPPPER (1978), RODRIGUES $(1979)$, etc.

2.6. Solos da ārea em estudo

Escassos sao os trabalhos sobre os solos da $\mathrm{Ba}-$ cia do Ribeirão do Lobo, que se localiza nos Municípios de Brotas, Itirapina e São Carlos, no estado de São Paulo.

A COMISSATO DE SOLOS DO CNEPA (1960) fez um levan tamento de reconhecimento dos solos da ārea em estudo, à nível de Grande Grupo, identificando: Terra Roxa Estruturada, Latossol Vermelho-Amarelo fase arenosa, Regossol e Solos Hidromōrfi$\cos$.

Recentemente, FREIRE et alii (1978) abordam ..uma revisão de informações referentes aos solos classificados pela COMISSAO DE SOLOS DO CNEPA (1960) e completam fazendo um levantamento categórico e cartograficamente semi-detalhado a nível de sub-grupo, inclusive identificando outros solos.

ALOISI et alie (1978), estimando parāmetros esta tîsticos da fração areia dos horizontes de dois perfis de Regos sois do cerrado da região abordada, concluiram que o transporte 
fluvial é o responsāvel pela origem desses solos e que existem pequenas variações granulomētricas nos horizontes dos solos es tudados, indicando homogeneidade nos dois perfis.

Em 1980, as quadrículas de São Carlos, Brotas e Araras foram mapeadas pedologicamente pelo Instituto Agronōmico de Campinas. Foi executado um levantamento semi-detalhado na quadrícula, mas, cartograficamente menos detalhado que FREI RE et alii 1978. fizeram na Bacia do Ribeirão do Lobo. 
27.

3. CARACTERISTICAS GERAIS DA AREA

\subsection{Localização}

A Bacia do Ribeirão do Lobo cobre uma área de. 21 149,375 ha, localizada na região centro leste do estado de São Paulo, entre os municípios de São Carlos, Brotas e Itirapina.

Segundo VILLELA e MATTOS (1975), esta bacia apre senta-se como uma sub-bacia do sistema Paranā-Tietê, pois o Ribeirão do Lobo é um dos formadores pelo lado esquerdo, do Rio Jacarē-Guaçū, afluente da margem direita do Rio. Tietê.

As coordenadas geogrāficas extremas, com base na folha de São Carlos SF23 - M.100(1968), editada pelo Instituto Geogrā́fico e Geológico do Estado de São Paulo, são as seguintes: $22^{\circ} 10^{\prime}$ e $22^{\circ} 20^{\prime}$ de latitude Sul; $47^{\circ} 45^{\prime}$. e $47^{\circ} 55^{\prime}$ de longitude Oeste de Grenwich: Figura 1. 


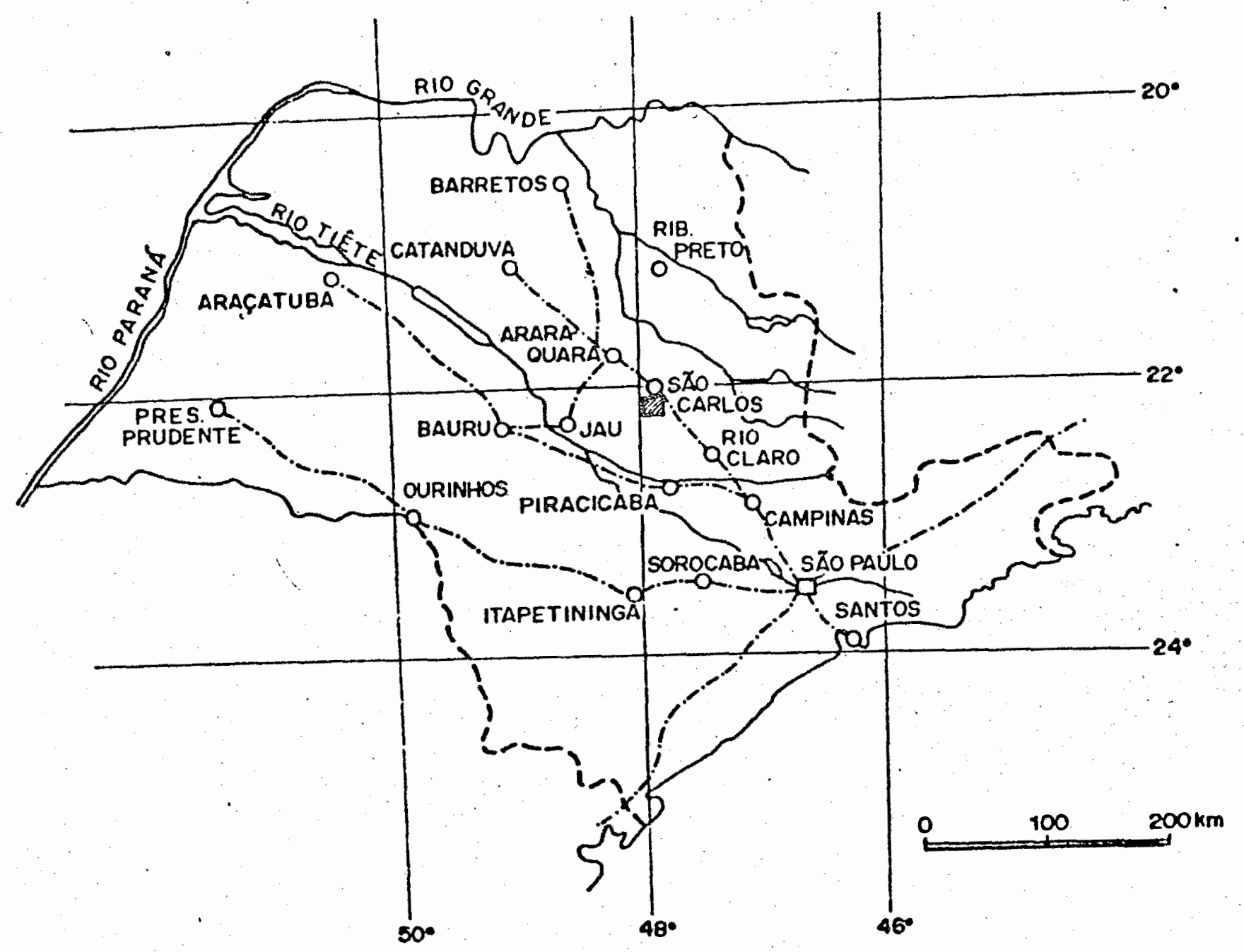

Figura 1 - Localização da ārea estudada. 
3.2. Clima.

Segundo FREIRE et alii (1978), o clima da região baseado na classificação de Koeppen, é do tipo Cwb, isto é, mesotērmico de inverno seco em que a temperatura do mês mais quen te não atinge $22^{\circ} \mathrm{C}$.

0 mès mais seco è julho, que é tambēm, o mês mais frio com temperatura média ao redor de $16,5^{\circ} \mathrm{C}$. 0 mês mais chuvo so é janeiro, sendo a precipitaçã் cerca de dez vezes maior que a de julho.

0 regime pluviométrico da região, de acordo com CAMARGO et alii (1974), é de 1400 a $1500 \mathrm{~mm}$ anúis.

\subsection{Relevo}

A maior parte da região apresenta um relevo pouco movimentado com desnīveis da ordem média de $50 \mathrm{~m}$. Altitudes máximas são encontradas nas proximidades da nascente do Ribei rao do Lobo (970 m) e da nascente do Ribeirão Itaquiri (945 m) e a altitude mínima é observada próximo a cabeceira da represa, entre os ribeirões do Lobo e Itaqueri $(700 \mathrm{~m})$. No entanto, devi do a presença de derrames de eruptivas bāsicas da Formação Serra Geral, que afloram ao sul, próximo a Itaqueri da Serra, observam-se os desníveis máximos que chegam a, aproximadamente, $300 \mathrm{~m}$. 
Segundo ALMEIDA (1964), a Bacia do Ribeirão do Lobo se inclui na província de cuestas arenito-basālticas, formadas no Arenito Botucatu e onde as variações de espessura do derrame basāltico, são responsáveis pelo desnível de 300 a 500m.

Segundo FREIRE et alii (1978), "nas regiões mais planas, considerando-se uma catena no sentido leste-oeste, a par tir do topo em direção à represa do Broa, encontra-se a seguinte distribuição teórica das unidades do mapeamento: Latossol Vermelho-Amarelo fase arenosa, Areia Quartzosa e Aluviões Hidro mōrficos. Na parte mais acidentada, considèrando-se uma sequēncia de solos no sentido sul-norte, a partir do topo em direção à represa, ocorrem as unidades de mapeamento classificadas como Podzōlico Vermelho-Amarelo, Terra Roxa Estruturada, Latossol Vermelho-Escuro, fase arenosa, Latossol Vermelho-Amarelo fase arenosa, Areia Quartzosa e Solos Orgānicos".

\subsection{Geologia}

De acordo com a CARTA GEOLOGICA DO PROJETO SAPUCAI - FOLHA DE CAMPINAS -SF-23-YA, BRASIL, DNPM (1979), (Figura 2), a região da Bacia do Ribeirão do Lobo apresenta rochas das seguintes unidades geológicas: Formações Botucatu, Serra Geral, Bauru, Pirambóia e Sedimentos Aluviais recentes. 


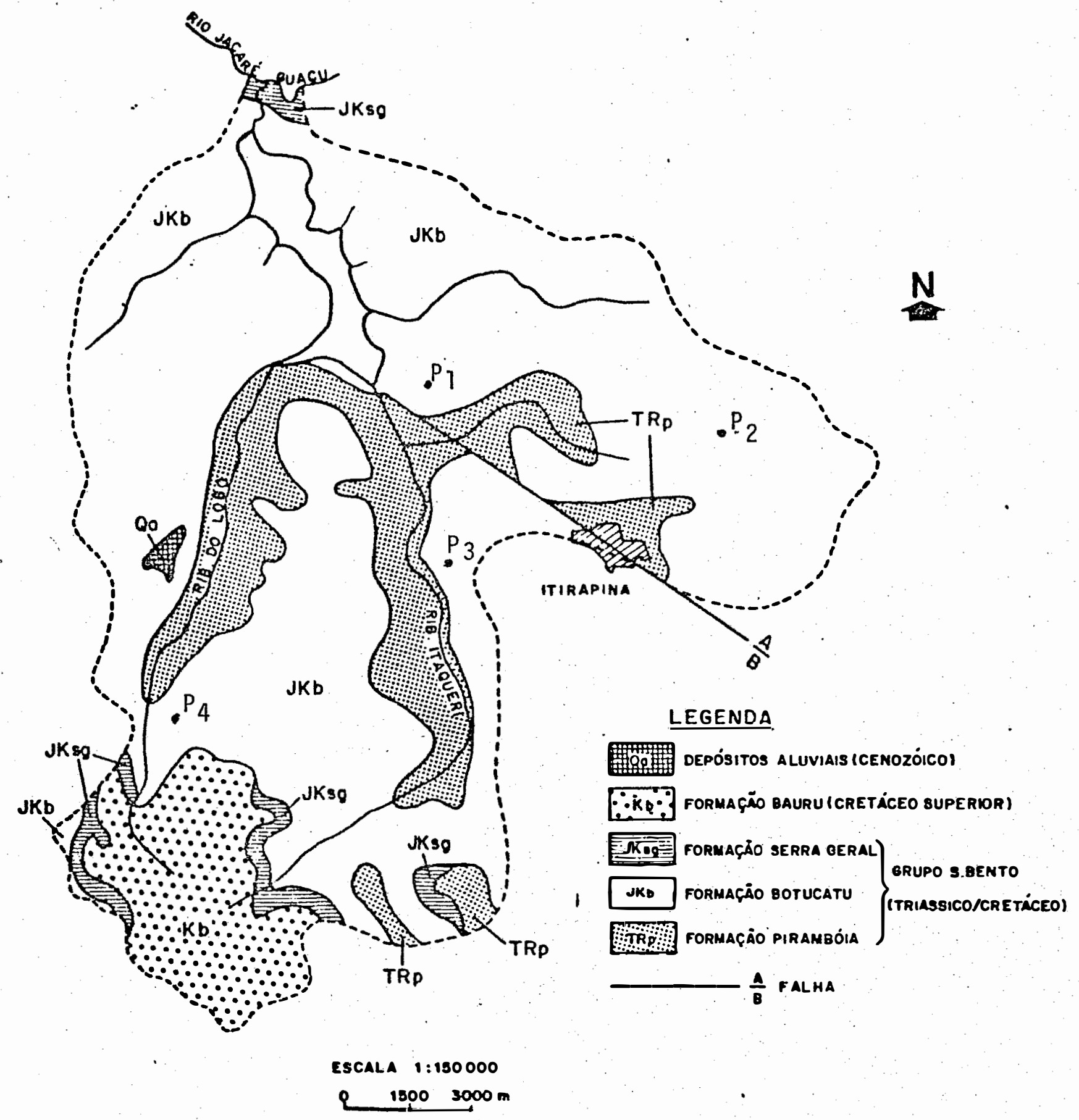

Figura 2 - Mapa Geológico da Bacia do Ribeirão do Lobo (BRASIL - D.N.P.M., 
A Formação Botucatu é constituĩda por arenitos róseos, avermelhados e esbranquiçados, finos a médios a muito fino, apresentando na base corpos de arenitos conglomeráticos e conglomerados. Contém, ainda, camadas de arenito de pouca espessura, comumente silicificada, intercalada entre os magmati tos da Formação Serra Geral.

Segundo SOARES (197.5), esta formação apresenta espessura bastante variāvel com uma média da ordem de 50 a $70 \mathrm{~m}$ e māxima de $150 \mathrm{~m}$. 0 contato inferior com a Formação Pirambōia é considerado concordante, apresentando uma exposição nas imediações da Serra de Itaqueri, sendo que o contato superior com as rochas basālticas da Formação Serra Geral é discordante.

BRASIL, DNPM (1979), observa que devido a suas características litológicas e sedimentares e a idade juro-cretá cea, vārios autores sugerem um ambiente de sedimentação desērtị co, eólico, ocorrendo na parte basal depósitos de origem torrencial e no topo, mais raramente, depósitos lacustres.

A Formação Serra Geral, sobrejacente ao Arenito Botucatu, segundo BRASIL, DNPM (1979) é constituída de uma sequência de lavas basálticas, toleîticas, de textura afanitica e cor cinza escura a preta. Próximo a base, ocorrem intercalações de arenitos finos a médios, com estratificação cruzada, idênti- 
cas aos do Arenito Botucatu. Soleiras e diques de diabásio, associados aos derrames são bastante comuns na ārea.

0 contato inferior com a Formação Botucatu e outras rochas mais antigas é discordante, enquanto que o contato superior com a Formação Bauru ocorre atravēs de discordāncia erosiva.

As rochas da Formação Bauru que capeiam discordantemente as eruptivas bāsicas da Formação Serra Geral, são de origem fluvio-lacustre segundo BRASIL, DNPM (1979), constituidas dominantemente por arenitos, com ocorrência de siltitos, ar gilitos e conglomerados. Os arenitos são de coloração variável, de granulação mēdia às vezes grosseiras e conglomerāticos,felds páticos, pouco a moderadamente calcíferos, com teor de matriz argilosa bastante variāvel.

Segundo ANDRADE e SOARES (1971), a espessura da Formação Bauru na região centro-leste do Estado de São Paulo é inferior a $100 \mathrm{~m}$, e as principais faixas continuas de ocorréncia distribuem-se em torno da cidade de São Carlos e entre as cidades de Itaquiri da Serra e São Pedro. 
A Formação Pirambōia, segundo SOARES (1972) tem uma idade que abrange o Triāssico Inferior ao Jurāssico Superior, com ambiente de formação subaquoso, lacustre e/ou fluvial. Segundo esse autor"constitui-se litologicamente de arenitos esbran quiçados, amarelados, avermelhados e róseos, médios a muito finos, com graos sub-arredondados e intercalações de siltitos e argilitos. Faz: um contato, na sua base, com a Formação Estrada Nova, atravēs de uma discordāncia erosiva". Acima dos sedimen tos aquosos da Formação Pirambōia, (DUARTE, 1980) cita que ocor rem arenitos róseos e amarelados, finos a médios, com grãos finos e proeminente, estratificação cruzada, característica da Formação Botucatu.

Os Sedimentos Holocênicos ocorrem nas baixadas marginais da represa, devido a uma profunda erosão determinada pelo declive para oeste da superficie da linha de cuestas. MARINS (1975), descreve a existēncia de uma superfície de aproximadamente $9 \mathrm{~km}^{2}$ desses sedimentos, sendo constituídos de cascalhos, areias, siltes e argilas. 0 material aluvionar é provenien te da erosão das rochas da Formação Serra Geral capeadas pelas rochas da Formação Bauru. (FREIRE et alii, 1978). 


\section{MATERIAIS}

\subsection{Solos}

Foram selecionadas e coletadas amostras de 4 per fis de solos da Bacia do Ribeirão do Lobo, classificados por FREIRE et alii como Latossol Vermelho-Amarelo' Distrófico ālico A fraco textura arenosa, Latossol Vermelho-Escuro Distrófico ālico A moderado textura médiá, Latossol Vermelho-Escuro Distrō fico ālico A fraco textura arenosa e Latossol Vermelho-Amarelo Distrōfico àlico A fraco textura média.

0s perfis receberam a designação de P1, P2, P3 e P4, correspondendo, respectivamente, a P6, P9, P10 e P18 do mapa de solos da região (FREIRE et alii, 1978). (Figura 3).

Uma localização mais detalhada dos perfis estuda dos encontra-se no mapa de localização da ärea. (Figura 4). 
36.

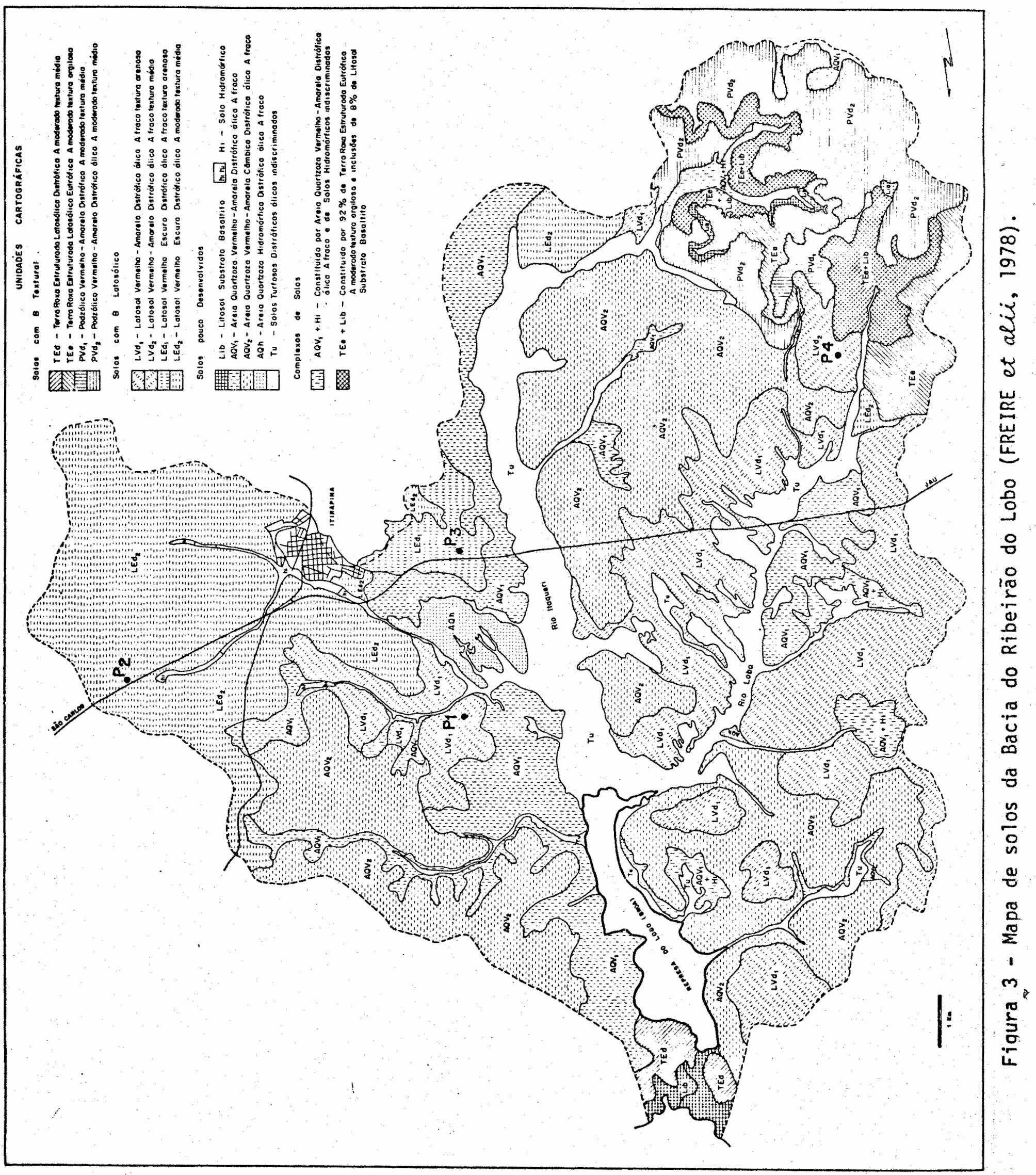




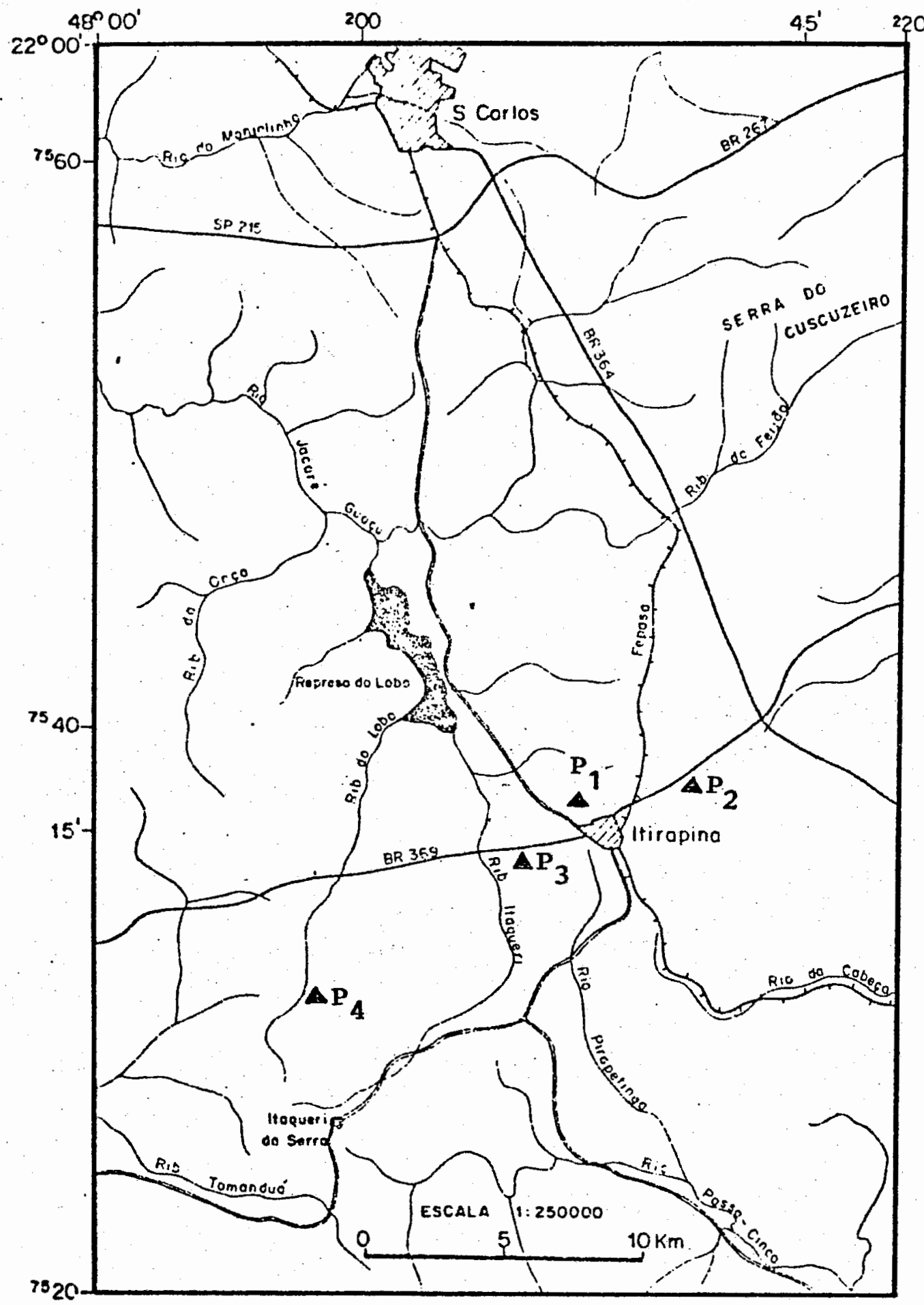

Figura 4 - Mapa da ārea de estudo com a localização dos Perfis (Projeto Sapucai, 1979 - Folha Campinas SF-23-YA). 
As caracteristicas dos perfis estudados são : as seguintes:

\section{PERFIL 1}

CLASSIFICAÇAO: Latossol Vermelho-Amarelo Distrōfico ālico A fra co, textura arenosa.

Haplorthox distropectico.

LOCALIZAÇA0: Vertente direita da Bacia da Represa do Lobo di $\underline{s}$ tante $6 \mathrm{~km}$ da barragem pela estrada municipal de São Carlos para Itirapina, na ārea pertencente ao Instituto Florestal de Itirapina.

GEOLOGIA: $\quad$ Formação Serra Geral.

RELEV0: Normal, suavemente ondulado, com longos declives, convexos, uniformes.

TOPOGRAFIA: Meia encosta de extensia elevação cuja declividade è de $2 \%$.

MATERIAL DE ORIGEM: Sedimentos Plio-Pleistocēnicos arenosos.

DRENAGEM: Acentuada e boa. 
EROSAO: Não aparente.

VEGETAÇAO: Campo cerrado com vegetação de gramíneas de porte elevado, arbustos e ārvores de pequeno porte:, típicas dessa formação vegetal, aglomerado em manchas esparsas.

ALTITUDE APROX IMADA: $720 \mathrm{~m}$.

MORF OLOGIA :

- A1 0- $20 \mathrm{~cm}$; pardo avermelhado (5YR 4/3), desuniforme com areia lavada, rōsea, dispersa; areia barrenta;ma ciço, que se rompe em granular, pequena, muito fraca; macio, friavel, não plāstico e não pegajo so; raizes fasciculadas, abundantes; macroporos $\underline{i}$ dade abundantes; atividade biológica muito abundante; transição ondulada, difusa.

B1 20- $55 \mathrm{~cm}$; cinza avermelhado escuro (5YR 4/2), desunifor me com areia lavada rósea, dispersa; barro areno so; maciço, que se rompe em blocos, médios, fracos; ligeiramente duro, friāvel, ligeiramente plástico e ligeiramente pegajoso; raizes finas, abundantes; macroporos abundantes, transição ondulada, difusa. 
40 .

B21 55- $80 \mathrm{~cm}$; vermelho amarelo (5YR 5/6); barro arenoso,com esqueleto de quartzo abundante; maciço, que se desfaz em blocos; ligeiramente duro, friável, plástico e pegajoso; macroporos comuns; raízes finas, abundantes; transição plana, difusa.

B22 80-100 cm; vermelho amarelo (5YR 5/8); barro arenoso,com cascalho de formato variável, predominando os a redondados, pequenos; maciço, poroso; duro,friāvel, plástico e pegajoso; macroporos comuns;tran sição plana, difusa.

B23 100-300 cm; amarelo avermelhado (5YR 6/8); barro arenoso, com cascalho de formato variāvel, predominando os arredondados, pequenos; maciço, poroso; duro, firme, plástico e pegajoso; macroporos comuns.

\section{PERFIL 2}

CLASSIFICAÇAO: Latossol Vermelho-Escuro Distrōfico ālico, A moderado, textura média. Haplorthox típico.

LOCALIZAÇAO: Estrada estadual para Itirapina, distando $3 \mathrm{~km}$ do entroncamento com a Via Washington Luiz. 
GEOLOGIA: Formação Serra Geral.

RELEV0: Normal, suavemente ondulado, com longos declives, convexos, desuniformes.

TOPOGRAFIA: Meia encosta de extensa elevação, cuja declividade é de $4 \%$.

MATERIAL DE ORIGEM: Sedimentos Plio-Pleistocênicos de textura mēdia.

DRENAGEM: $\quad$ Moderada.

EROSAO: Laminar ligeira a moderada e sulcos rasos ocasio nais.

VEGETAÇAO: Reflorestamento com eucalipto, recentemente implantado .

ALTITUDE APROXIMADA: $800 \mathrm{~m}$.

MORF OLOGIA : 
Ap $\quad 0-15 \mathrm{~cm}$; cinza avermelhado escuro $(5,0 Y R \quad 4 / 2)$, marche tado com areia lavada rōsea, abundante; barro arenoso; maciço que se rompe em granular, média a pequena, muito fraco; ligeiramente duro, muito friāvel, não plāstico e não pegajoso; raĩzes fasciculadas finas muito abundantes; transição plana, gradual.

A3 15- $45 \mathrm{~cm}$; cinza avermelhado escuro $(5,0 \mathrm{YR} 4 / 2)$, salpicado coli areia lavada rósea abundante; barro are noso; maciço, que se rompe em fragmentos irregu lares pequenos, fracos; ligeiramente duro, friā vel, não.plāstico e ligeiramente pegajoso; raízes fasciculadas finas abundantes; transição pla na, gradual.

B21 45- $60 \mathrm{~cm}$; pardo avermelhado (5,0YR 4/4), com manchas escuras na parte superior; barro arenoso; maciço, que se rompe em blocos, grandes, fracos; du ro, friāvel, ligeiramente plástico e ligeiramen te pegajoso; raizes fasciculadas médias, raras; transição plana, gradual. 
B22 60- $90 \mathrm{~cm}$; pardo avermelhado $(5,0$ YR $4 / 4)$, com veias escuras; barro arenoso; maciço, que se rompe em blocos grandes muito fracos; duro, friāvel, ligeiramente plástico e ligeiramente pegajoso;raí zes mēdias raras; acumulações de areia lavada comuns; transição plana, difusa.

B3 90-115 cm; pardo avermelhado (5YR 5/4), com manchas ver melhas $(2,5 Y R$ 4/8) grandes, esparsas; barro are noso; maciço, poroso; duro, firme, ligeiramente plástico e ligeiramente pegajoso; raízes mēdias raras; transição plana, difusa.

C 115+cm; alaranjado (5,OYR 4/6); barro arenoso; maciço, poroso; duro, firme, plástico e pegajoso; raīzes médias abundantes.

\section{PERF IL. 3}

CLASSIFICAÇÃo: Latossol Vermelho-Escuro Distrōfico ālico A fra co, textura arenosa'. Haplorthox paleudultico.

LOCALIZAÇAO: Cabeceira da Bacia da Represa do Broa, prōximo à entrada para Itirapina. 
GEOLOGIA: $\quad$ Formação Serra Geral.

RELEV0: Normal, suavemente ondulado, com declives longos, convexos, desuniformes.

TOPOGRAFIA: Topo de extensa elevação, 'cuja declividade ē de $40 \%$.

MATERIAL DE ORIGEM: Sedimentos arenosos Plio-Pleistocēnicos.

DRENAGEM: $\quad$ Bem drenado.

EROSAO: Laminar ligeira e sulcos médios ocasionais na ba se das elevações.

VEGETAÇAO: Cerrado constituído por arvores típicas e vegeta ção de gramĩneas.

ALTITUDE APROXIMADA: $780 \mathrm{~m}$.

MORFOLOGIA :

Ap $\quad 0-15 \mathrm{~cm}$; pardo avermelhado escuro (5YR 3/4); barro arenoso; granular, média a grande, moderada; macio, friāvel, ligeiramente plāstico e ligeiramente pe gajoso; raizes fasciculadas finas e grossas muito abundantes; transição plana, gradual. 
B1 $15-25 \mathrm{~cm}$; vermelho escuro $(2,5 \mathrm{YR} 3 / 6)$; areia barrenta; blocos pequenos que se rompem em granular, media a grande, forte; duro, friāvel, ligeiramente plāstico e ligeiramente pegajoso; raízes fas ciculadas abundantes; porosidade muito abundante; galerias biológicas grandes, esparsas, comuns; transição plana, clara.

B21 25- $60 \mathrm{~cm}$; pardo escuro avermelhado $(2,5 \mathrm{YR} 3 / 4)$.com mar chetamento de areia lavada rōsea, abundante, areia barrenta; blocos, médios a grandes, fra cos; macio, friāvel, ligeiramente plāstico e lị geiramente pegajoso; raĩzes fasciculadas mēdias e grossas comuns; porosidade abundante; transição plana, difusa.

B22 60-120 cm; vermelho (2,5YR 4/6); barro arenoso; blocos, médios a grandes, muito fracos; duro, firme,plās tico e pegajoso; raízes grossas esparsas; poro: sidade abundante; galerias biológicas comuns transição difusa.

B23 120-180 cm; vermelho (2,5YR 4/6); barro arenoso; com frag mentos de canga laterītica grandes, comuns; maciço, poroso; ligeiramente duro, firme, plāstico e pegajoso; porosidade abundante. 


\section{PERF IL 4}

CLASSIFICAÇÃo: Latossol Vermelho-Amarelo Distrōfico ālico A fra co, textura mēdia.

Haplorthox típico.

LOCALIZAÇÃO: Cabeceira da Bacia da Represa do Broa.

GEOLOGIA: Formação Serra Geral.

RELEV0: Normal, ondulado, com declives fortes, convexo e desuniforme.

TOPOGRAFIA: Topo de extensa elevação, cuja declividade ē de 12 a $15 \%$.

MATERIAL DE ORIGEM: Sedimentos policīclicos Cenozóicos.

DRENAGEM: Bem drenado.

EROSAO: Laminar ligeira e sulcos rasos, ocasionais.

VEGETAÇÁ்: Pastagem de gramīneas altas, arbustos e ārvores esparsas. 
MORFOLOGIA:

Ap $\quad 0-10 \mathrm{~cm}$; pardo avermelhado (5YR 4/4); barro argilo-are noso, com linhas irregulares de cascalho de quart zo, que sugerem estratificação do material de origem; maciço, rompendo-se em blocos irregula res, grandes, fracos; muito duro, firme, ligeira mente plāstico e pegajoso; raízes fasciculadas, abundantes; porosidade baixa; transição difusa.

A12 10-30 cm; pardo avermelhado (5YR 4/4); barro argilo-are noso, cam linhas paralelas de cascalho de quartzo e canga laterítica; blocos grandes, fracos; du ro, firme, plāstico e pegajoso; raízes fascicula das abundantes; porosidade baixa; transição difu sa.

B21 30- $75 \mathrm{~cm}$; vermelho amarelado (5YR 4/6); barro argilo-are noso, com cascalho abundante de quartzo e canga laterítica, esparso; maciço, poroso; duro, firme, plāstico e pegajoso; raízes fasciculadas abundan tes; transição difusa.

B22 75-140 cm; vermelho amarelado (5YR 4/6);barro argilo-are noso, com cascalho de quartzo e canga laterítica, abundantes, esparsos; maciço, poroso;ligeiramente duro,friāvel,plástico e pegajoso;raỉzes fascicula das abundantes. 


\subsection{Instrumental}

\subsubsection{Peneiras}

Foi utilizado jogo de peneiras US Standard, de malhas 1000 u, 500 u, 250 u, 150 u e 50 u, para a separação das diferentes frações da areia em cada amostra dos horizontes.

\subsubsection{Microscópio}

Na anālise mineralógica e na avaliação do arredondamento, foi utilizado microscópio de origem alemã, fabrị cação Carl Zeiss, com aumentos de 80,320 e 800 vezes.

\subsubsection{Centrīfuga}

Na separação dos resîduos leve e pesado, utilizou-se centrífuga marca Internacional no 2 , a aproximadamente $4000 \mathrm{rpm}$. 
49.

5. METOQDO

\subsection{Amostragem}

Foram abertas trincheiras com profundidade suficiente para a coleta de amostras dos värios horizontes de cada perfil. Para localização das trincheiras, seguiu-se indicação de FREIRE et alii (1978).

Coletou-se, então, uma amostra de cerca de $2 \mathrm{~kg}$ de material de cada horizonte num total de 20 amostras.

\subsection{Anālise coranulomētrica}

Utilizou-se o mētodo da pipeta, segundo recomen dações de KILMER e ALEXANDER (1949). Foram usados $10 \mathrm{~g}$ de TFSA de cada amostra e calgon-hexametafosfato de sódio como agente dispersante. A fração areia total foi fracionada em jogo de pe neiras, descrito em 4.2.1. 
50 .

\subsection{Preparo das amostras.}

5.3.1. Separação da fração areia total

A fração areia total foi obtida através da anālise granulomëtrica a partir de $10 \mathrm{~g}$ TFSA, conforme descrito em 5.2 .

5.3.2. Eliminação da matéria orgānica e dos óxidos de ferro livres

Para eliminação da matēria orgānica, da fração areia, efetuou-se tratamento com peróxido de hidrogênio a $30 \%$ em meio ligeiramente ácido, em banho maria, conforme recomenda ção de JACKSON (1956).

Na eliminação dos óxidos de ferro livres foi utilizado o ditionito-citrato-bicarbonato, através do método descrito por AGUILERA e JACKSON (1953).

\subsubsection{Separação da fração leve e pesada}

A separaçao do resíduo pesado foi efetuada na fração areia muito fina, por ser esta a fração mais fina, justaposta à dominante. Segundo RUBEY (1933), este procedimento justifica-se pelo fato de se esperar que o resíduo pesado se. concentre,devido à sua maior densidade, nesta fração de areia. 
Os minerais pesados foram separados, com a utili zaçao de bromofórmio, de densidade 2,85. Uma vez separados no tubo de centrífuga, utilizou-se a técnica de congelamento da parte inferior do tubo, contendo o residuo, pesado, facilitando a obtenção dos resĩduos leve e pesado.

\subsubsection{Montagem das lâminas}

Apōs separação dos magnēticos e não magnēticos por meio de imã, as frações leves e pesadas foram montadas em lâminas de microscōpio, com resina "likeside" de indice de refração semelhante ao Bálsamo de Canadá. Na maioria das vezes utilizou-se toda a fração pesada na montagem das lâminas.

\subsection{Anālise mineralōgica,}

A composição mineralógica qualitativa e quantita tiva da fração areia muito fina de cada horizonte, foi determinada microscopicamente. Efetuou-se a contagem e caracterização de 300 grânulos em cada lâmina e ou em toda lâmina quando a escassez dos minerais não permitia que se chegasse 300 grānulós.

Apōs contagem procedeu-se a verificação dos mine rais restantes da làmina, a fim de assinalar a possível ocor rência de minerais raros que pudessem escapar à observação na contagem dos primeiros 300 minerais. 


\subsection{Arredondamento}

O grau de arredondamento dos minerais da fração areia muito fina, foi obtido utilizando-se de técnica de compa raçao visual dos grānulos (KRUMBEIN, 1941 ).

Foram examinados 100 grānulos em cada lâmina em bora MÅRCONI et alii (1970) tenha concluido que 25 grānulos se riam suficientes e sUGUIO (1973) considere representativa uma amostra de 50 grânulos ou mais.

\subsection{Anālise estatistica}

No cālculo dos parâmetros estatísticos,para ana lise granulométrica, foram desprezadas as frações argilas e silte, em face da mobilidade que essas frações apresentam no perfil, levando com isso a resultados enganosos. Os teores das frações areia, recalculados a $100 \%$, foram lançados em papel de probabilidade aritmética, utilizando-se escala $\emptyset$ ISuguio, 1973 ) obtendo-se as curvas de frequencia acumulada. Das curvas de frequência acumulada foram extraîdos os valores necessários aos cālculos dos parâmetros, proposto por FOLK e WARD (1957) e descritos em 3.5 . 
53.

6. RESULTADOS E DISCUSSAOO

\subsection{Anālise granulométrica}

Os resultados da anālise granulomētrica referen. tes aos perfis P1, P2, P3 e P4, estão apresentados nas Tabelas 1 e 2. A anālise estatistica, estā baseada na fração areia recalculada a $100 \%$ Tabelas 3 e 4 .

- Os valores calculados dos parāmetros estatisti$\cos M_{Z}, \Gamma_{I}, S_{K_{I}}$ e $K_{G}$ (FOLK e WARD, 1957) estão relacionados na Tabela 5 . 
54 .

Tabela 1 - Anālise granulométrica dos perfis P1 e. P2.

\begin{tabular}{lrllllllll} 
Hori- & $\begin{array}{l}\text { Profun } \\
\text { zontes }\end{array}$ didade & \multicolumn{8}{c}{$\%$} \\
\cline { 3 - 8 } & a.m.g. & a.g. & a.m. & a.f. & a.m.f. silte argila \\
A1 & $0-20$ & 1,2 & 2,6 & 14,7 & 54,7 & 10,9 & 5,1 & 10,8 \\
B1 & $20-55$ & 2,0 & 3,2 & 17,4 & 45,1 & 13,0 & 5,7 & 13,6 \\
B21 & $55-80$ & 0,6 & 1,9 & 14,1 & 43,9 & 19,6 & 6,1 & 13,8 \\
B22 & $80-100$ & 0,7 & 2,5 & 15,4 & 41,6 & 18,0 & 8,9 & 12,9 \\
B3 & $100+$ & 0,7 & 2,8 & 15,0 & 41,6 & 17,2 & 7,9 & 14,8
\end{tabular}

\section{Perfil 2}

Ap $\begin{array}{rlllllll}0-15 & 0,3 & 2,4 & 24,6 & 45,2 & 10,8 & 2,8 & 13,9\end{array}$

B3 $\begin{array}{llllllll}15-45 & 0,1 & 1,8 & 20,3 & 45,2 & 13,7 & 4,9 & 14,0\end{array}$

$\begin{array}{lllllllll}\text { B21 } 15-60 & 0,1 & 2,4 & 25,1 & 41,0 & 11,3 & 5,0 & 15,1\end{array}$

$\begin{array}{llllllll}\text { B22 } 60-90 & 0,3 & 2,6 & 26,3 & 38,7 & 11,3 & 4,1 & 16,7\end{array}$

B3 $90-115 \cdot 0,4 \quad 3,0 \quad 24,9 \quad 38,9 \cdot 11,4 \quad 3,8 \quad 17,6$

C $\quad 115+\quad 0,3 \quad 2,2 \quad 25,5 \quad 43,9 \quad 6,6 \quad 4,6 \quad 16,9$ 
Tabela 2 - Anālise granulométrica dos perfil P3 e P4.

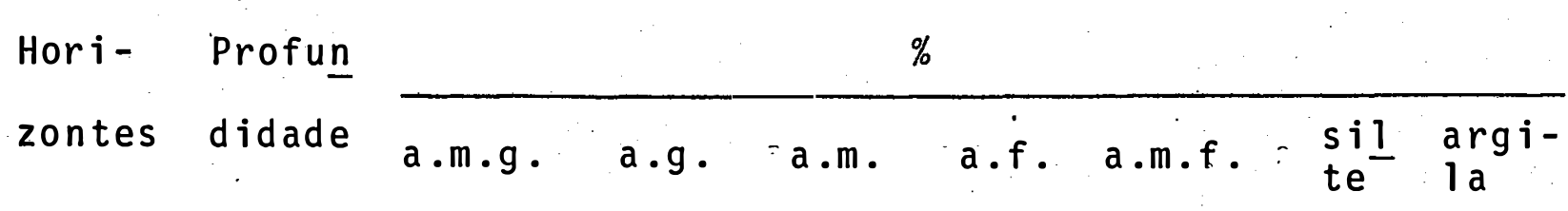

Perfil 3

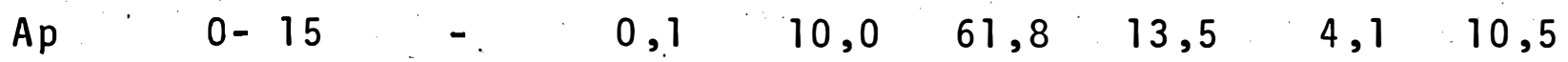

B1 $\quad 15-25 \quad-\quad 0,1 \quad 10,7 \quad 60,0 \quad 10,1 \quad 5,4 \quad 10,7$

B21 $25-60 \quad 0,2 \quad 0,1 \quad 11,8 \quad 59,4 \quad 11,5 \quad-17,0$

B22 60-120 - $\quad-\quad 9,960,0 \quad 12,9 \quad-\quad 17,2$

B23 $120+\quad-\quad 0,1 \quad 10,4 \quad 59,8 \quad 11,3 \quad-\quad 18,4$

Perfil 4

Ap $\quad 0-10 \quad 2,0 \quad 14,2 \quad 33,3 \quad 23,9 \quad 1,8 \quad 5,2 \quad 19 ; 6$

$\begin{array}{lllllllll}\text { A12 } & 10-30 & 1,0 & 10,0 & 38,2 & 23,3 & 2,3 & 5,3 & 19,9\end{array}$

$\begin{array}{lllllllll}\text { B2 } 1 & 30-75 & 1,3 & 9,3 & 27,8 & 28,9 & 3,0 & 6,0 & 23,7\end{array}$

$\begin{array}{llllllll}\text { B22 } & 75+\quad 0,7 & 7,9 & 26,6 & 26,2 & 3,9 & 6,0 & 28,7\end{array}$ 
Tabela 3 - Granulometria da fração areia recalculada a $100 \%$ dos perfis $P 1$ e $P 2$.

\begin{tabular}{llllll}
\hline \multirow{2}{*}{ Horizontes } & \multicolumn{4}{l}{} & \\
\cline { 2 - 6 } & a.m.g. & a.g. & a.m. & a.f. & a.m.f. \\
\hline
\end{tabular}

\section{Perfil $1-$ LVdl}

$\begin{array}{llllll}\text { A1 } & 1,42 & 3,09 & 17,48 & 65,04 & 12,96 \\ \text { B1 } & 2,48 & 3,97 & 21,56 & 55,89 & 16,11 \\ \text { B21 } & 0,75 & 2,37 & 17,60 & 54,81 & 24,47 \\ \text { B22 } & 0,90 & 3,20 & 19,70 & 53,20 & 23,02 \\ \text { B3 } & 0,91 & 3,62 & 19,40 & 53,82 & 22,25\end{array}$

Perfil 2 - LEd2

$\begin{array}{lrrrrr}\text { Ap } & 0,36 & 2,88 & 29,53 & 54,26 & 12,97 \\ \text { A3 } & 0,12 & 2,22 & 25,03 & 55,73 & 16,89 \\ \text { B21 } & 0,13 & 3,00 & 31,41 & 51,31 & 14,14 \\ \text { B22 } & 0,38 & 3,28 & 33,21 & 48,86 & 14,27 \\ \text { B3 } & 0,51 & 3,82 & 31,68 & 49,49 & 14,50 \\ \text { C } & 0,38 & 2,80 & 32,48 & 55,92 & 8,41\end{array}$


Tabela 4 - Granulometria da fração areia recalculada a $100 \%$ dos perfis $\mathrm{P3}$ e P4.

\begin{tabular}{|c|c|c|c|c|c|}
\hline \multirow{2}{*}{ Horizontes } & \multicolumn{5}{|c|}{$\%$} \\
\hline & $\mathrm{a} \cdot \mathrm{m} \cdot \mathrm{g}$. & a.g. & $\mathrm{a} \cdot \mathrm{m}$. & $a \cdot f$. & $a \cdot m . f$. \\
\hline 。 & & Perfi & - LEdl & & \\
\hline Ap & - & 0,12 & 11,71 & 72,37 & 15,81 \\
\hline B1 & - & 0,12 & 12,75 & 71,51 & 15,61 \\
\hline B21 & 0,24 & 0,12 & 14,22 & 71,57 & 13,86 \\
\hline B22 & - & - & 11,96 & 72,46 & 15,58 \\
\hline B23 & - & 0,12 & 12,75 & 73,28 & 13,85 \\
\hline & & Perfi & $-L V d 2$ & & \\
\hline Ap & 2,66 & 18,88 & 44,28 & 31,78 & 2,39 \\
\hline A12 & 1,34 & 13,37 & 51,07 & 31,15 & 3,07 \\
\hline B21 & 1,85 & 13,23 & 39,54 & 41,15 & 4,27 \\
\hline B22 & 1,05 & 12,10 & 40,73 & 40,12 & 5,97 \\
\hline
\end{tabular}


58.

Tabela 5 - Valores dos parâmetros estatisticos, calculados segun do FOLK e WARD (1957) utilizando a escala $\emptyset$.

\begin{tabular}{ccccc}
\hline Horizontes & Média & $\begin{array}{c}\text { Grau de } \\
\text { Seleção }\end{array}$ & $\begin{array}{c}\text { Graude } \\
\text { Assimetria } \\
S_{I}\end{array}$ & $\begin{array}{c}\text { Curtose } \\
K_{I}\end{array}$ \\
\hline
\end{tabular}

Perfil 1

$\begin{array}{lllll}\text { A1 } & 2,45 & 0,71 & -0,16 & 1,09 \\ \text { B1 } & 2,41 & 0,94 & -0,08 & 1,18 \\ \text { B21 } & 2,71 & 0,81 & -0,19 & 0,93 \\ \text { B22 } & 2,60 & 0,87 & -0,10 & 0,94 \\ \text { B3 } & 2,63 & 0,84 & -0,09 & 0,98\end{array}$

Perfil 2

$\begin{array}{lllll}\text { Ap } & 2,41 & 0,71 & 0,01 & 0,99 \\ \text { A3 } & 2,57 & 0,78 & 0,06 & 0,89 \\ \text { B21 } & 2,44 & 0,79 & 0,04 & 0,91 \\ \text { B22 } & 2,23 & 0,69 & -0,03 & 0,93 \\ \text { B3 } & 2,40 & 0,79 & 0,10 & 0,92 \\ \text { C } & 2,31 & 0,68 & 0,21 & 1,12\end{array}$

Perfil 3

$\begin{array}{lrrrr}\text { Ap } & 2,77 & 0,56 & -0,07 & 1,01 \\ \text { B1 } & 2,70 & 0,60 & 0,08 & 1,00 \\ \text { B21 } & 2,67 & 0,59 & 0,01 & 0,97 \\ \text { B22 } & 2,74 & 0,57 & 0,05 & 0,86 \\ \text { B23 } & 2,70 & 0,57 & 0,03 & 1,03 \\ & & \text { Perfi1 } 4 & & \\ \text { Ap } & 1,70 & 0,92 & 0,01 & 1,04 \\ \text { A12 } & 1,76 & 0,81 & 0,05 & 1,05 \\ \text { B21 } & 1,88 & 0,88 & -0,01 & 1,03 \\ \text { B22 } & 1,95 & 0,87 & 0,01 & 1,02\end{array}$




\subsubsection{Diâmetro médio $(M z)$}

Das medidas de tendência central, o diāmetro mēdio é inegavelmente a mais importante. Geologicamente, é a que melhor reflete a média geral do tamanho das partículas de um se dimento, sendo afetado por fatores como tamanho dos grânulos do material de origem, pela fonte de suprimento do material, condi ções de transporte e processo de deposição do material (SUGuIo, 19731 .

Os valores de diâmetro médio obtidos (Tabela 5) mostram uma certa uniformidade entre os perfis P1, P2 e P3, com valores de diâmetro médio entre $\emptyset 2,23$ e 2,77.

Por sua vez, o perfil P4, difere granulometricamente dos demais, tendo valores de $\emptyset$ variando entre 1,70 e 1,95, caracterizando-se como areia mēdia.

Observa-se, ainda, uma certa homogeneidade entre os horizontes dos perfis em estudo.

\subsubsection{Grau de seleção $\left(\Gamma_{I}\right)$}

0 grau de seleção, considerado aspecto importante na anālise granulométrica de sedimentos, permite medir o grau de dispersão dos dados, em torno da tendência central, de 
modo que, quanto menor for o valor do desvio médio, melhor serā o selecionamento do material, ou seja, menor serā a dispersão dos dados em relação a média.

Todos os perfis estudados (Tabela 5 ), mostram ho mogeneidade entre seus horizontes, sendo constituidos de material moderadamente selecionado (Folk e Ward, in SUGUIo, 1973) Nota-se apenas que o P3 em comparação com os demais, tem valo res de 0,56 a 0,60 , o que indica uma tendência para material bem selecionado, e que o P4 tem valores de 0,81 a 0,92, com tendência para o pobremente selecionado.

\subsubsection{Grau de assimetria $\left(S_{K_{I}}\right)$}

Segundo Suguio (1973), o grau de assimetria de um sedimento mede a tendência que os dados apresentam de se dis persarem de um lado ou do outro da média. Em uma distribuição, simétrica, o diāmetro mēdio e a mediana coincidem e, portanto não existe assimetria.

Os resultados da Tabela 5 indicam que o Pl apresenta valores de $S_{K_{I}}$ negativos, mostrando existência de uma cur va com cauda voltada para o lado mais grosseiro da distribuição e que os outros perfis apresentam todos seus horizontes (com ex ceçao do horizonte $C$ do $P 2)$, com valores de $S_{K_{I}}$ entre $-0,07$ e 0,08 sendo considerados aproximadamente simétricas (Folk e Ward, in sUguio, 1973). 


\subsubsection{Curtose $\left(K_{G}\right)$}

A medida de curtose mostra a relação existente entre a dispersão na parte central e nas extremidades das curvas. Para curvas de distribuição normal, a curtose é igual a 1,0. Valores de $K_{G}$ inferiores a 1 mostram maior dispersão dos dados, provocando o achatamento das curvas e valores de $K_{G}$ superiores a 1 indicam melhor selecionamento na parte central da distribuição, originando curvas mais agudas.

De maneira geral, todos os horizontes dos perfis estudados apresentam valores de $K_{G}$ entre 0,90 a 1,11 com raras exceções, indicando assim predomināncia de curvas mesocūrticas.

Apenas os horizontes $B 1, C$ e $B 22$, respectivamente dos perfis P1, P2 e P3 não apresentam uniformidade, em relação aos valores dos outros horizontes do mesmo perfil. Assim, o B1 do P1 e C do P2 apresentam curvas leptocūrticas entre hori zontes de curvas mesocūrticas e O B22 do P3 apresenta curva pla ticūrtica entre horizontes de curvas mesocūrticas, isto é, hor zontes de material com $K_{G}$ próximo a normalidade com horizontes de material melhor selecionado. 
0 perfil mais uniforme em relação a curtose, ē - P4, onde todos os horizontes mostram curvas mesocūrticas com valores de $K_{G}$ prōximos a normalidade.

\subsubsection{Considerações gerais}

Os resultados da anālise granulométrica (Tabelas 1 e 2). da granulometria da fração areia recalculada a $100 \%$ (Ta belas 3 e 4 ), bem como das curvas de frequência acumulada (Figu ras 5 a 8 ) e de distribuição granulométrica de horizontes de ca da perfil (Figura 9), mostram que os perfis estudados se distri buem em duas categorias distintas: uma compreendida pelos perfis P1, P2 e P3, que apresentam uma tendência para se desloca rem para o lado das frações mais finas, tendo como moda a areia fina e uma porcentagem de argila cerca de 30 a $40 \%$ menor que a do perfil P4. Estes perfis apresentam, ainda curvas de frequēncia acumulada dos horizontes sobrepostas e curvas de distribuiçao de frequência de tamanho normalmente simétricas. Outra cate goria compreende o perfil P4, que mostra menores valores de $\emptyset$. A porcentagem da fração argila cresce consideravelmente, sendo a fração modal constituída de areia média, seguida pela areia fina, tendo ainda curvas de distribuição de frequência de tamanho com tendēncia assimētrica.

Provāveis ocorrências de descontinuidade litológica a longo dos perfis não podem ser indicadas pelos resulta- 
63.

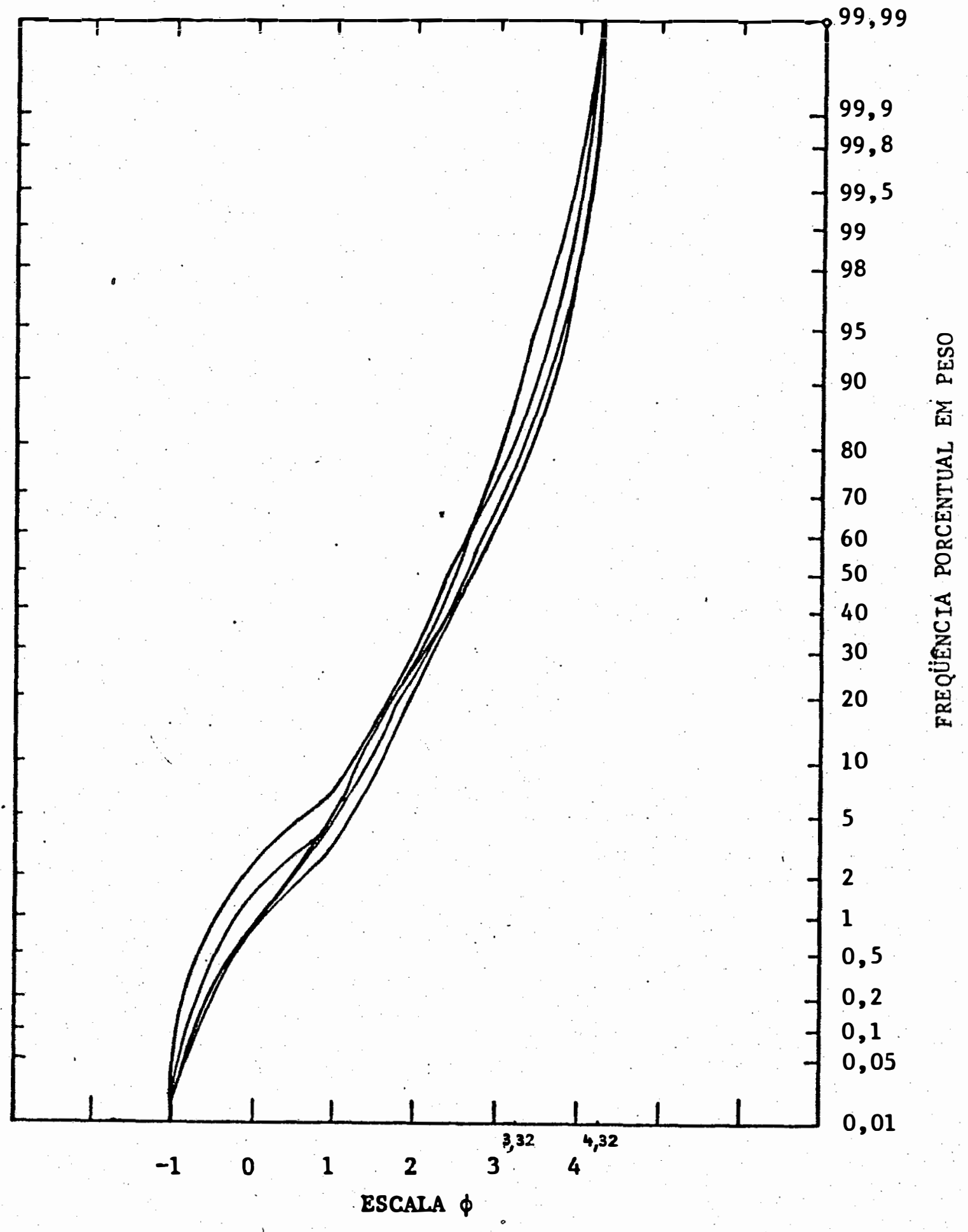

Figura 5 - Curvas acumulativas dos horizontes do Perfil $P_{1}$. 


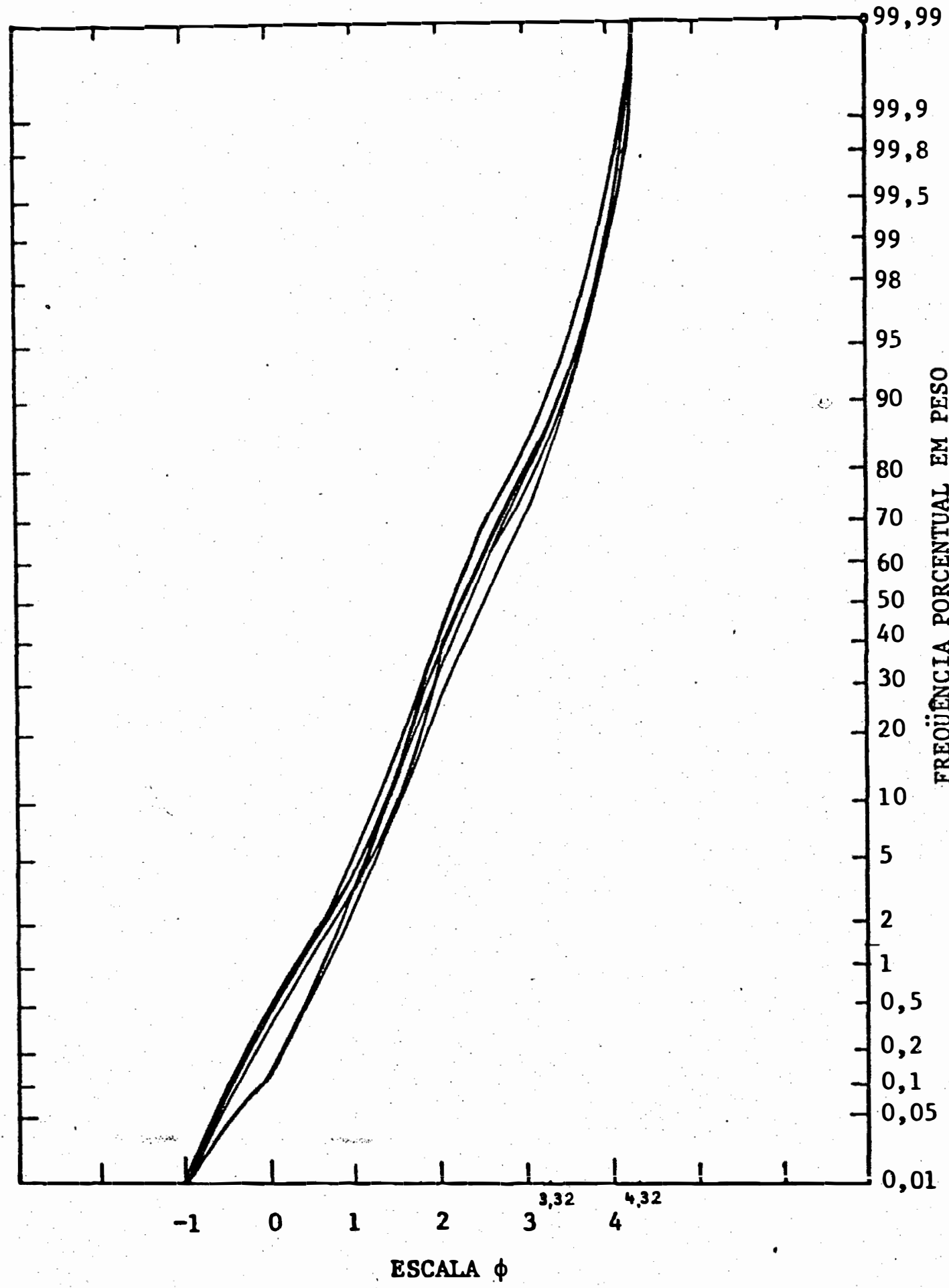

Figura 6 - Curvas acumulativas dos horizontes do Perfil $P_{2}$. 
65.

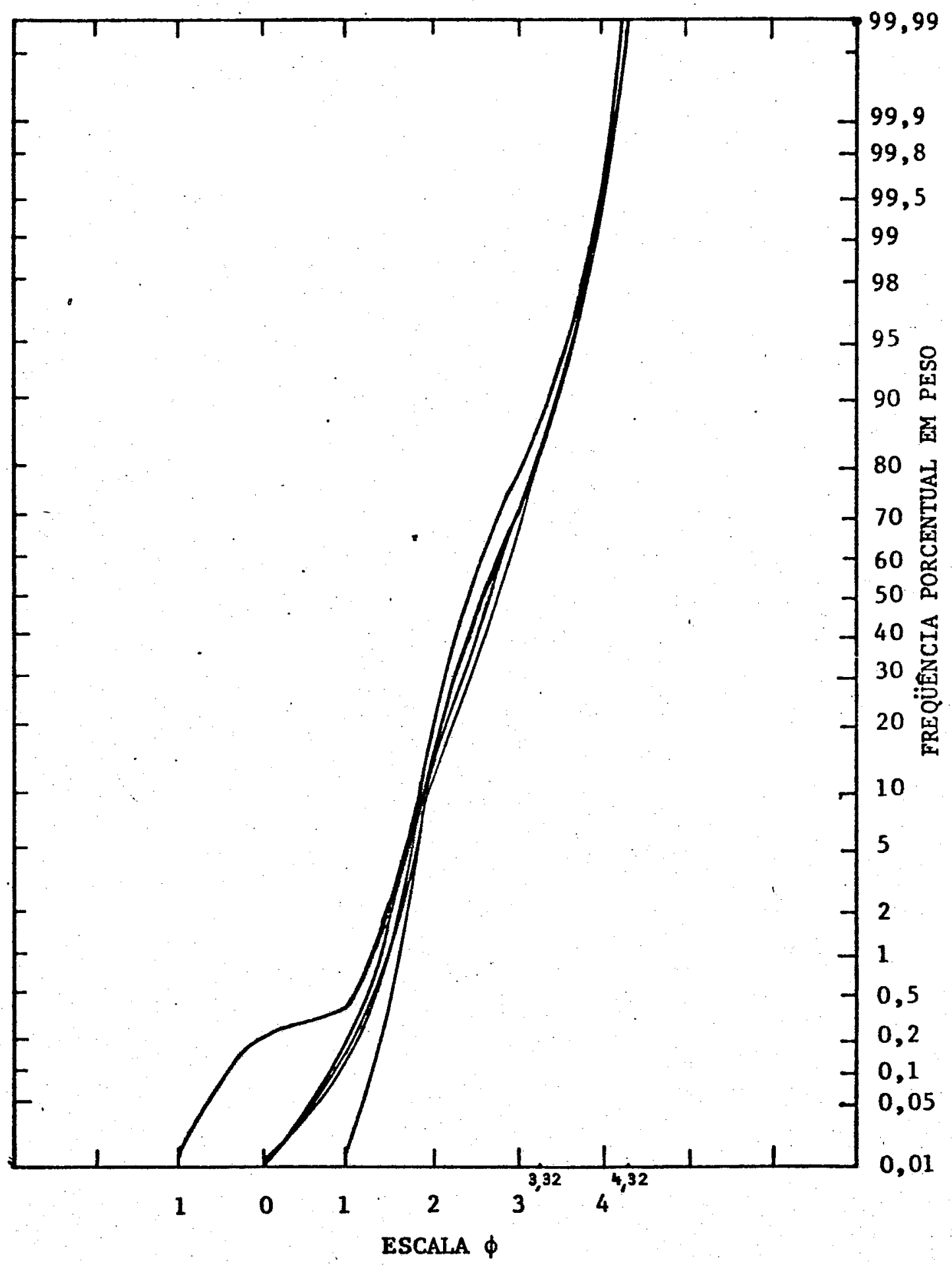

Figura 7 - Curvas acumulativas dos horizontes do Perfil $P_{3}$. 
66.

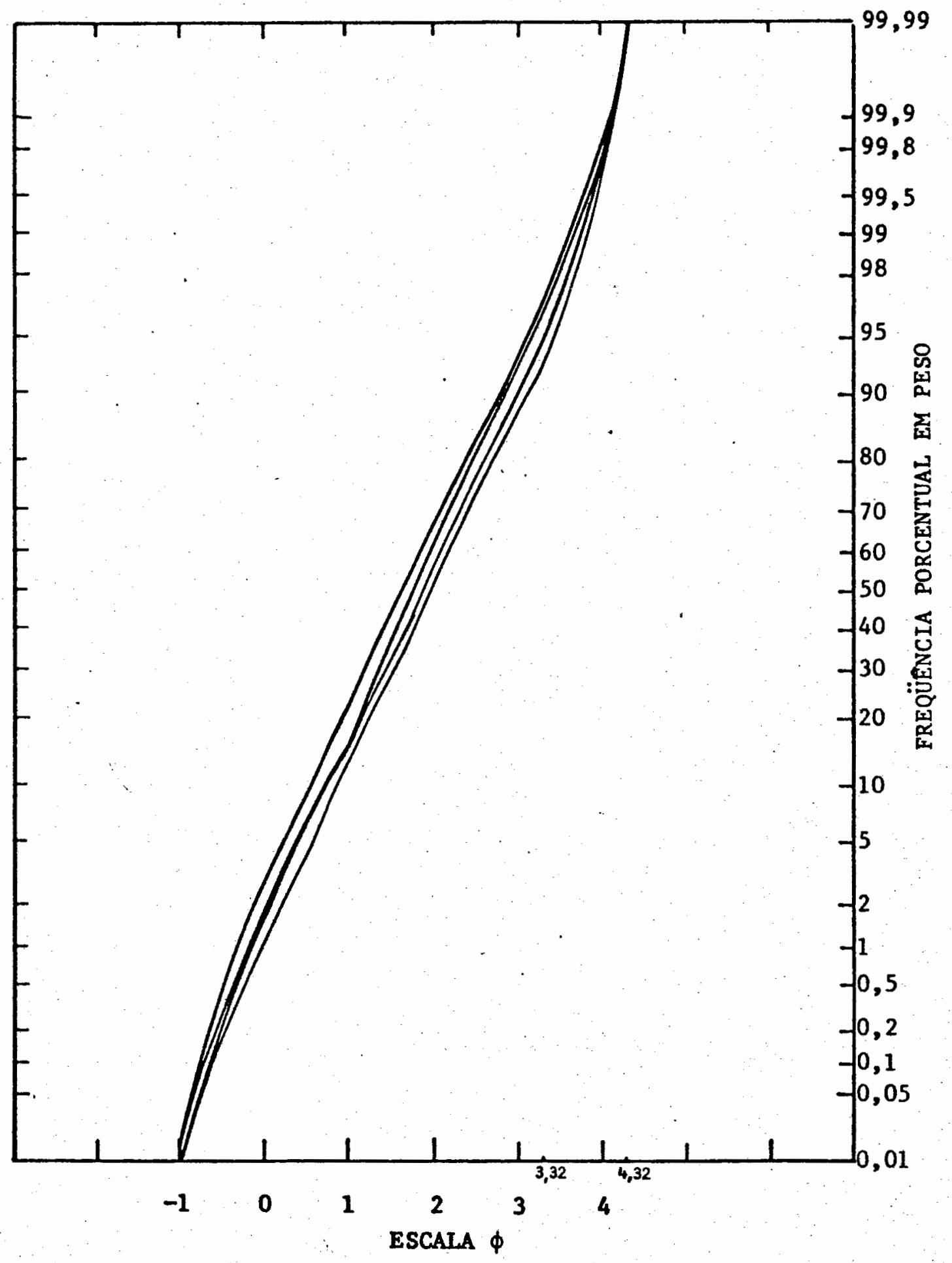

Figura 8 - Curvas acumulativas dos horizontes do Perfil $\mathrm{P}_{4}$. 
67.
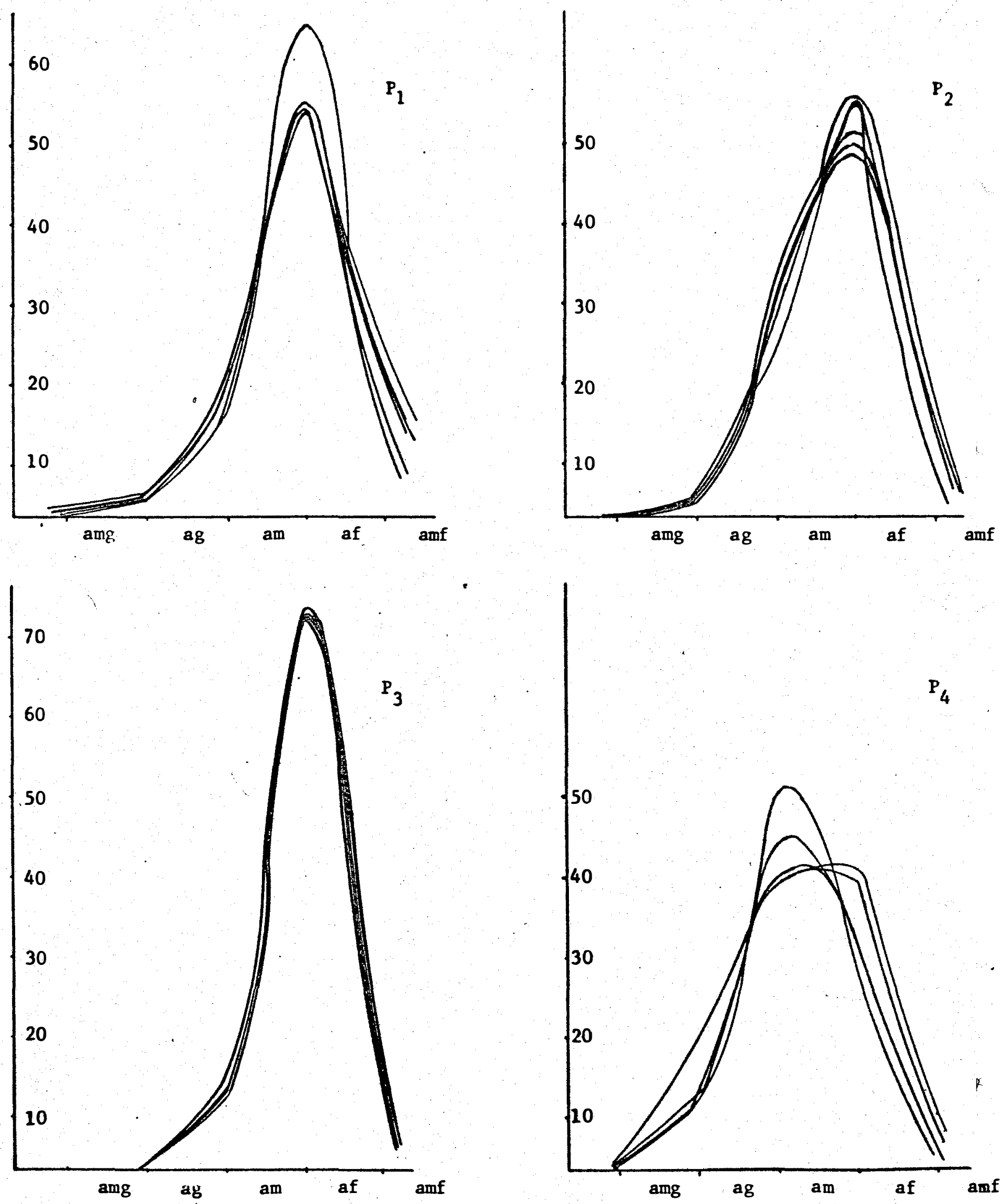

Figura 9 - Curvas de freqüēncia de distribuição granulomētrica dos Perfis. 
dos das anālises granulométricas, mas indicios de ocorrência po dem ser sugeridos pelos valores de grau de seleção, grau de assimetria e curtose dos horizontes B1 (P1), C (P2) e B22 (P3), sem que, entretanto, seja um dado conclusivo.

\subsection{Anālise mineralōgica}

6.2.1. Descrição dos minerais

\section{Zirconita}

Em todos os horizontes ocorre grande variação nas caracteristicas dos grānulos de zirconita. Apresentam formas prismāticas e esféricas, cristais normalmente sem inclusões, mas as vezes bem desenvolvidos, grânulos límpidos até escuros, ocorrendo alguns amarelados. Generalizando, podemos dividir em dois grupos distintos de zirconita: um tipo predominante em todos os perfis, incolor, bem arredondado, às vezes amarelado e sempre de tamanho menor; outro tipo incolor, com cristais bem desenvolvidos mas de ocorrencia mais restrita. 0 arredondamento e invariavel mente elevado, mesmo nos grānulos prismāticos.

Turmalina

Os grānulos de turmalina sao típicos, apresentando-se com maior frequência na cor parda esverdeada. Ocasionalmen 
te, ocorrem cores azul clara, verde e preta. Mostram intenso pleocroismo, elevado grau de arredondamento e são raras as ve=zes que aparecem com inclusões.

\section{Estaurolita}

Ocorrem grānulos de formas irregulares e muitas fraturàs, com aparência de "queijo suiço", típico deste mineral. A cor predominante é a amarela clara, às vezes de tons fracamen te avermelhados, mas e frequente a ocorréncia de grānulos de co res amarela escura até parda. São pouco pleocróicas e pobres em inclusões.

\section{Minerais Opacos}

0 elenco de minerais opacos e muito restrito. Fo ram reconhecidos ilmenita e alguns grānulos de magnetita que ocasionalmente passaram pela separação através do imã. Entretan to, uma vez que a distinção entre ambas, ao microscópio, so e possível em casos extremamente favorāveis, resolveu-se fazer a contagem em conjunto. Apresentam-se invariavelmente como granulos sub-angulares e sub-arredondados a grānulos bem arredonda dos. 


\subsubsection{Perfil Pl}

0 exame da Tabela 6 permite verificar baixos teo res de minerais pesados, que entre os horizontes variam de 1,42 a $1,86 \%$.

Entre os minerais pesados, predominam opacos (magnetita e ilmenita), com teores superiores a $60 \%$, o qual a $\underline{u}$ menta no B21 para $70 \%$ e no B3 para $73 \%$ em função de uma diminuição na quantidade de zirconita ou de turmalina (Tabela 8).

Os teores dos minerais transparentes e opacos fo ram recalculados para $100 \%$. 0 exame das Tabelas 7 e 8 mostra uma nîtida predominância da zirconita em todos os horizontes, in clusive com aumento de mais de $50 \%$ na passagem do Bl para o B21, com consequente e significativa antipatia pela turmalina, caracterizada por uma consequente diminuição de aproximadamente $50 \%$ no seu teor. Por sua vez, a estaurolita, terceiro mineral na esciala de abundāncia, não sofre muitas variações nos seus teo res a nao ser no B21, onde ocorre o aumento de zirconita, cond $\underline{i}$ cionado à diminuição da turmalina e também da estaurolita.

Os valores calculados para a relação zirconital turmalina (Tabela 7) mostram ocorrência de variações acentuadas e inclusive a antipatia da zirconita pela turmalina (Figura 10 ). 
Tabela 6 - Porcentagem de minerais leves e pesados da fração areia muito fina do $\mathrm{Pl}$.

\begin{tabular}{ccc}
\hline Horizontes & $\%$ leve & $\%$ pesado \\
\hline A1 & 98,24 & 1,76 \\
B1 & 98,24 & 1,86 \\
B21 & 98,57 & 1,43 \\
B22 & 98,58 & 1,42 \\
B3 & 98,45 & 1,55 \\
\hline
\end{tabular}

Tabela 7 - Frequência dos minęrais pesados da fração areia mui = to fina do Pl.

\begin{tabular}{lccccc}
\hline Minerais & \multicolumn{5}{c}{ Horizontes } \\
\cline { 2 - 6 } & A1 & B1 & B21 & B22 & B3 \\
\hline Zirconita & 30 & 44 & 61 & 61 & 34 \\
Turmalina & 44 & 45 & 18 & 19 & 24 \\
Estaurolita & 22 & 17 & 10 & 19 & 14 \\
Total transparente & 96 & 106 & 89 & 99 & 72 \\
Opacos : & 204 & 194 & 211 & 201 & 198 \\
No de gränulos & 300 & 300 & 300 & 300 & 300 \\
Relação Z/T & 0,68 & 0,98 & 3,39 & 3,21 & 1,41 \\
\hline
\end{tabular}


Tabela 8 - Porcentagem dos minerais pesados do Pl (os minerais transparentes estão recalculados para $100 \%)$.

\begin{tabular}{lllll}
\hline Horizontes & Opacos & Zi & Tu & Es \\
\hline A1 & 68,00 & 31,25 & 45,84 & 22,94 \\
B1 & 64,67 & 41,52 & 42,46 & 16,05 \\
B21 & 70,33 & 68,52 & 20,22 & 11,22 \\
B22 & 67,00 & 61,61 & 19,18 & 19,18 \\
B3 & 73,34 & 47,26 & 33,31 & 19,43 \\
\hline
\end{tabular}

A relação zirconita/turmalina apresenta pontos

de inflexão nas curvas (Figura 11): passa do valor 0,98 do B1 para 3,39 no B21, se mantēm no B22 e no B3 sofre uma diminuição atingindo apenas 0 valor 1,41 .

Embora a descrição morfológica não apresente diferenças significativas entre os horizontes B1 e B21, a variação na relação zirconita/turmalina, aliada às variações nos va lores de diâmetro mēdio, grau de seleção, grau de assimetria e de curtose (Tabela 5), sugere e comprova a ocorrência de descon tinuidade litológica no perfil. 


\subsubsection{Perfil P2}

0 perfil P2; possui aproximadamente as mesmas ca racterísticas mineralógicas do Pl. Constitui-se de uma porcenta gem um pouco maior de minerais pesados com teores variando de 1,21 a 2,66\%, (Tabela 9).

Entre os minerais pesados, existe uma maior predominância dos opacos (magnetita e ilmenita) com teores sempre superiores a $59 \%$, chejando a $79,67 \%$ no horizonte C (Tabelas .10 e 11$)$.

Neste perfil, nao existe um mineral transparente dominante. Zirconita predomina nos horizontes $A 3, B 21$ e $C$ e tur malina nos horizontes Ap, B22 e B3. Estaurolita aparece como o mineral menos abundante dos transparentes e com razoável dimi nuição em teor no horizonte B22. A antipatia zirconita-turmalina é caracterizada nos horizontes B22 e B3, tanto que possui re 1 ação zirconita/turmalina 0,63 e 0,48 respectivamente, contra 1,34 do B21 e 1.39 do C (Tabelas 10 e 11 e Figuras 12 e 13).

Embora os valores acima indiquem presença de de $\underline{s}$ continuidades litológicas entre os horizontes B21/B22 e B3-C,es ta só pode ser confirmada no horizonte C atravēs de variações significativas nos valores de grau de assimetria (de 0,10 a 0,21 ) e curtose $(0,92$ a 1,12$)$. 
Tabela 9 - Porcentagem de minerais leves e pesados da fração areia muito fina do P2.

\begin{tabular}{ccc}
\hline Horizontes & $\%$ leve & $\%$ pesado \\
Ap & 98,79 & 1,21 \\
A3 & 98,71 & 1,29 \\
B21 & 97,34 & 2,66 \\
B22 & 98,09 & 1,91 \\
B3 & 98,38 & 1,62 \\
C & 97,80 & 2,20 \\
\hline
\end{tabular}

Tabela 10 - Frequencia dos minerais pesados da fração areia mui to fina do $P 2$.

\begin{tabular}{lrrrrrr}
\hline \multirow{2}{*}{ Minerais } & \multicolumn{7}{c}{ Horizontes } \\
& Ap & A3 & B21 & B22 & B3 & C \\
Zirconita & 32 & 46 & 43 & 45 & 30 & 25 \\
Turmalina & 43 & 36 & 32 & 71 & 63 & 18 \\
Estaurolita & 18 & 16 & 15 & 9 & 14 & 7 \\
Total transparente & 93 & 98 & 90 & 125 & 107 & 50 \\
Opacos & 207 & 202 & 210 & 175 & 193 & 196 \\
Nọ de grânulos & 300 & 300 & 300 & 300 & 300 & 246 \\
Relação Z/T & & & & & &
\end{tabular}




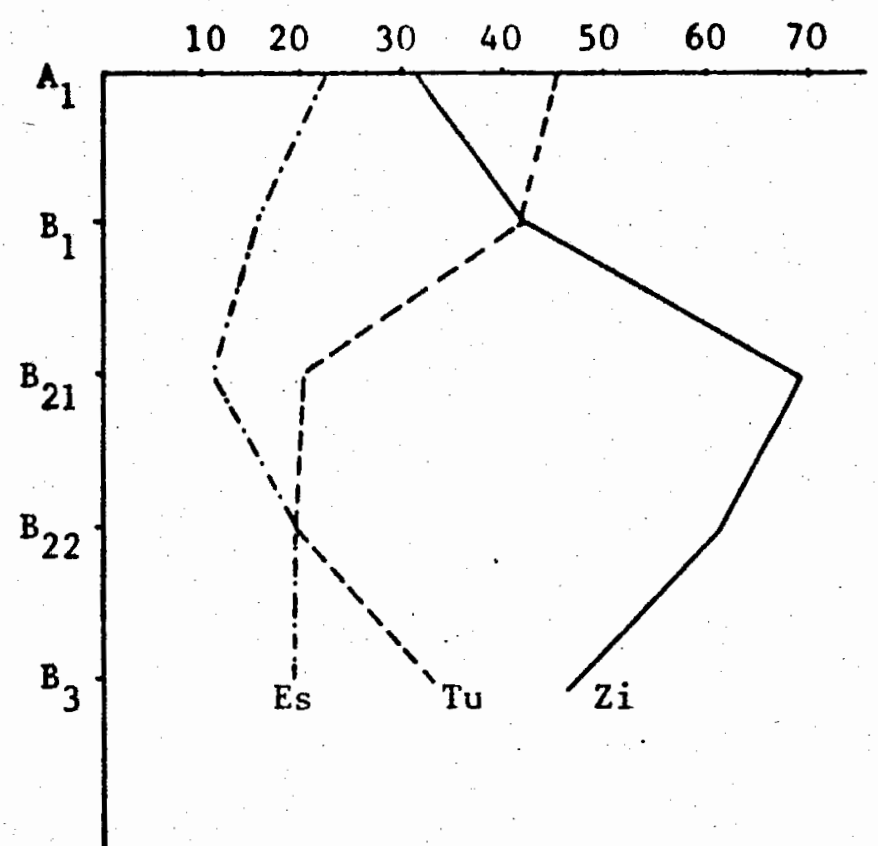

Fig. 10 - Porcentagem de Zirconita, Turmalina e Estaurolita do $\mathrm{P}_{1}$.

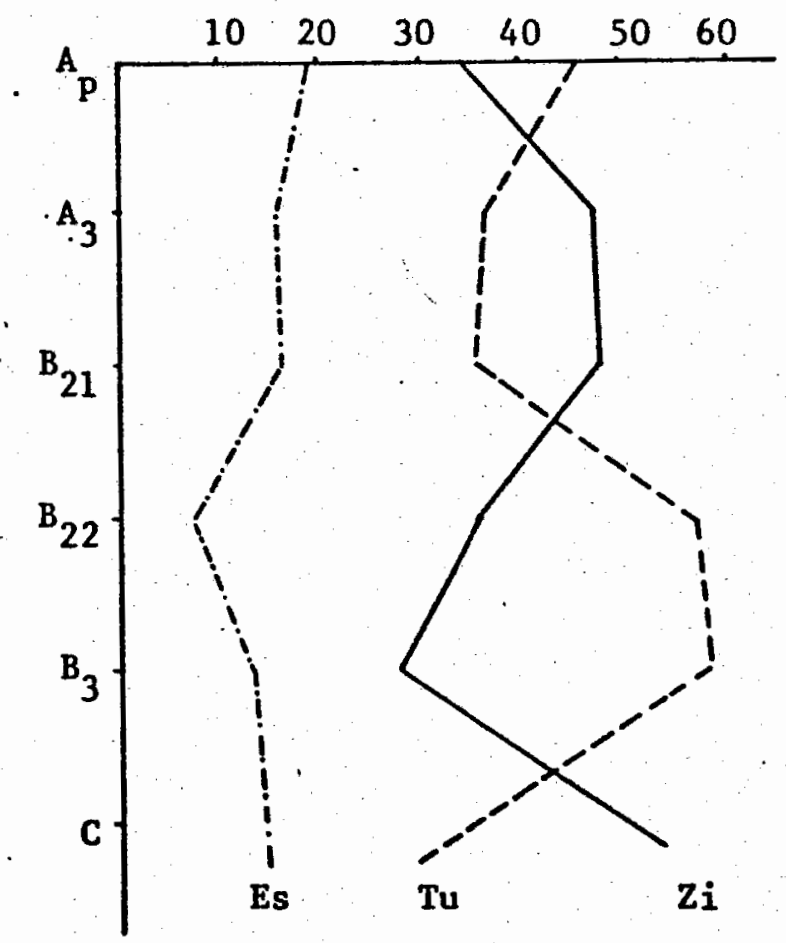

Fig. 12 - Porcentagem de Zirconita, Turmalina e Estaurolita do $P_{2}$.

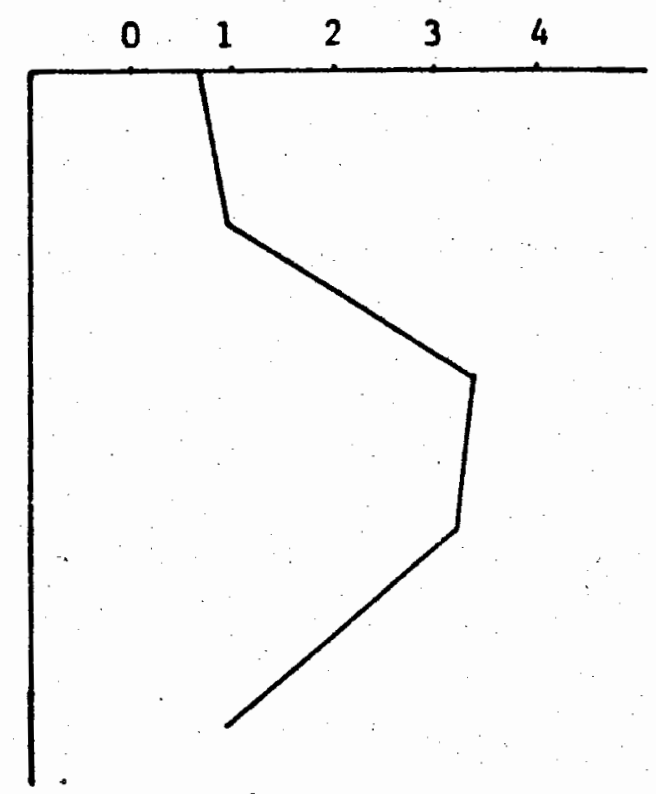

Fig. 11 - Relação Zirconita/Turma lina do $\mathrm{P}_{1}$.

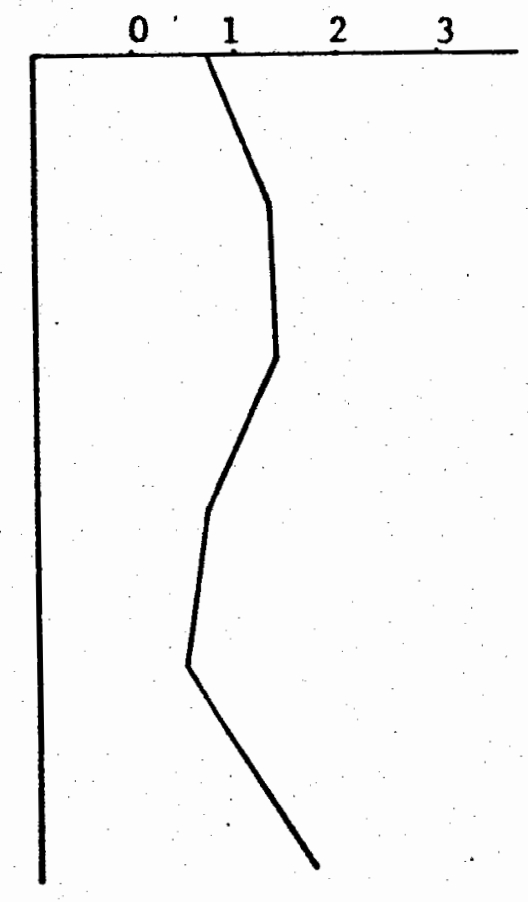

Fig. 13 - Relação Zirconita/Turma lina do $\mathrm{P}_{2}$. 
Tabela 11 - Porcentagem dos minerais pesados do P2 (os minerais transparentes somam $100 \%$ ).

\begin{tabular}{lllll}
\hline Horizontes & Opacos & $\mathrm{Zi}$ & $\mathrm{Tu}$ & Es \\
\hline Ap & 69,00 & 34,42 & 46,22 & 19,36 \\
A3 & 67,33 & 46,92 & 36,73 & 16,31 \\
B21 & 70,00 & 47,77 & 35,57 & 16,67 \\
B22 & 58,33 & 36,00 & 56,80 & 7,20 \\
B3 & 64,33 & 28,03 & 58,87 & 13,09 \\
C & 79,67 & 49,98 & 36,01 & 14,02 \\
\hline
\end{tabular}

\subsubsection{Perfil 3}

Os resultados do perfil P3: (Tabelas 12, 13 e 14) mostram que houve variação na porcentagem de minerais pesados em relação aos perfis P1 e P2. Os teores variam de 2,85 a $3,15 \%$ neste perfil. Este aumento deve ser atribuido ao acréscimo nos opacos, enquanto que os minerais transparentes diminuiram consideravelmente, chegando a contagem máxima de apenas 53 em 300 grā nulos determinados. Os minerais opacos (magnetita e ilmenita) ocorrem em teores que variam de 82 a $88 \%$. 
Tabela 12 - Porcentagem de minerais leves e pesados da fração areia muito fina do P3.

\begin{tabular}{ccc}
\hline Horizontes & $\%$ leve & \% pesado \\
\hline Ap & 96,85 & 3,15 \\
B1 & 97,15 & 2,85 \\
B21 & 96,18 & 3,82 \\
B22 & 97,12 & 2,88 \\
B23 & 97,14 & 2,86 \\
\hline
\end{tabular}

Tabela 13 - Frequência dos minerais pesados da fração areia muí to fina do P3.

Minerais

Horizontes

\begin{tabular}{lcrrrr} 
& Ap & B21 & B21 & B22 & B23 \\
\hline Zirconita & 22 & 24 & 23 & 22 & 12 \\
Turmalina & 21 & 12 & 10 & 12 & 5 \\
Estaurolita & 10 & 8 & 7 & 13 & 4 \\
Total transparente & 53 & 44 & 40 & 47 & 21 \\
Opacos & 247 & 256 & 260 & 253 & 161 \\
Nọ de grânulos & 300 & 300 & 300 & 300 & 182 \\
Relação Z/T & 1,05 & 2,00 & 2,30 & 1,83 & 2,40 \\
\hline
\end{tabular}


Tabela 14 - Porcentagem dos minerais pesados do P.3 (os minerais transparentes somam $100 \%$ ).

Horizontes

Ap

B 1

B2 1

B22

B23
Opacos

82,33

85,33

86,67

84,33

88,46
Zi

41,48

54,53

57,54

46,78

57,11
$\mathrm{Tu}$

39,62

27,27

24,98

25,53

23,83
Es

18,85

18,20

17,48

27,63

19,06

0 elenco restrito de minerais pesados transparen tes exibe uma predominância da zirconita em relação a turmalina e estaurolita, que ocorrem praticamente em iguais teores. A antipatia zirconita-turmalina é notada desde os primeiros horizon tes, assumindo a relação $Z / T$ sucessivamente os valores 1,05, $2,00,2,30,1,83$ e 2,40 . As Figuras 14 e 15 ilustram esta an tipatia e os pontos de inflexão da curva da relação zirconital turmalina, particularmente para o horizonte B22, que possui tam bēm antipatia da zirconita/estaurolita, fato este não observado em outros horizontes dos perfis estudados. 
79.
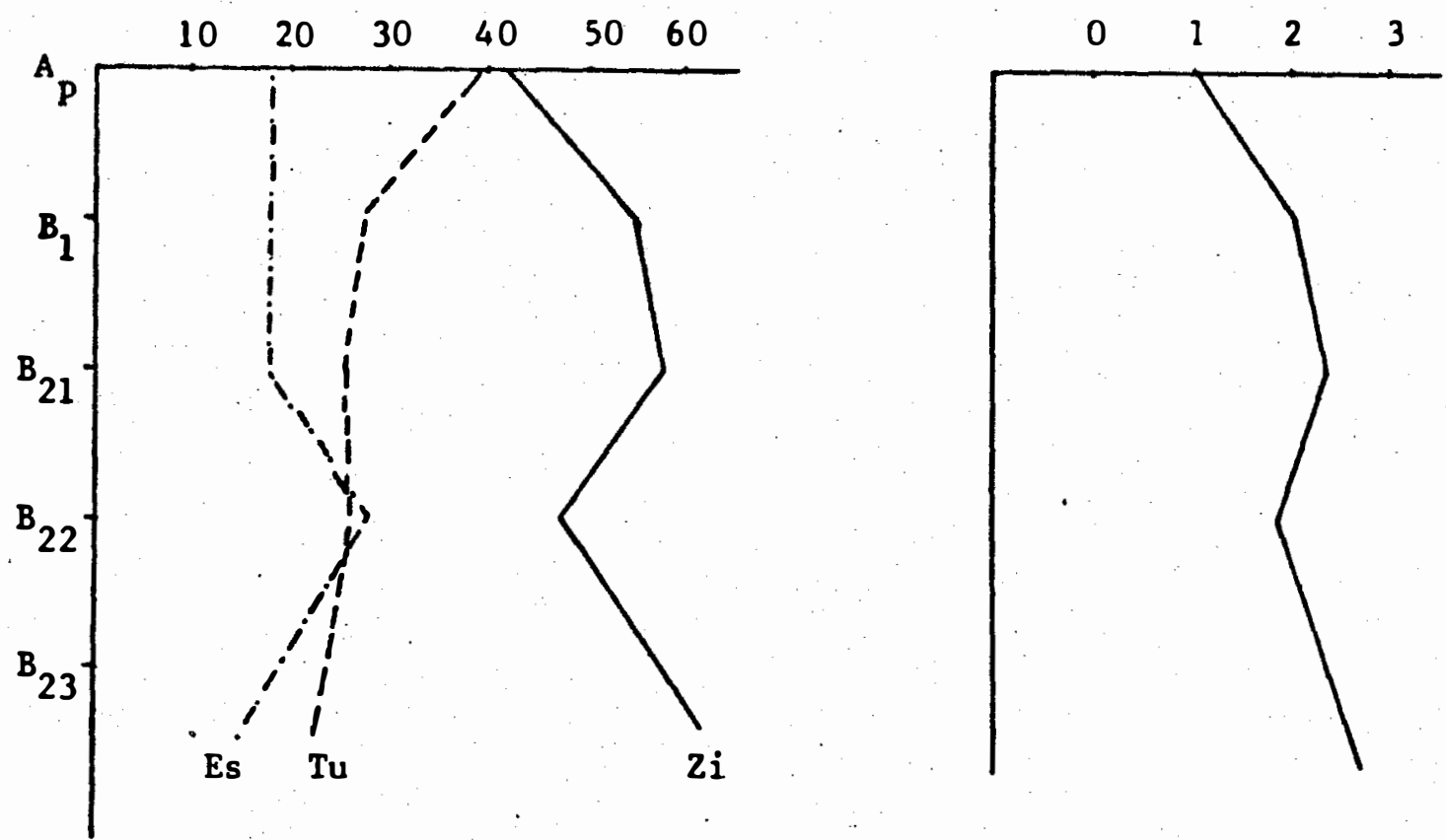

Figura 14 - Porcentagem de Zirconita, Turmalina e Estaurolita do P3.

Figura 15 - Relação Zirconita/Turmalina do P3.

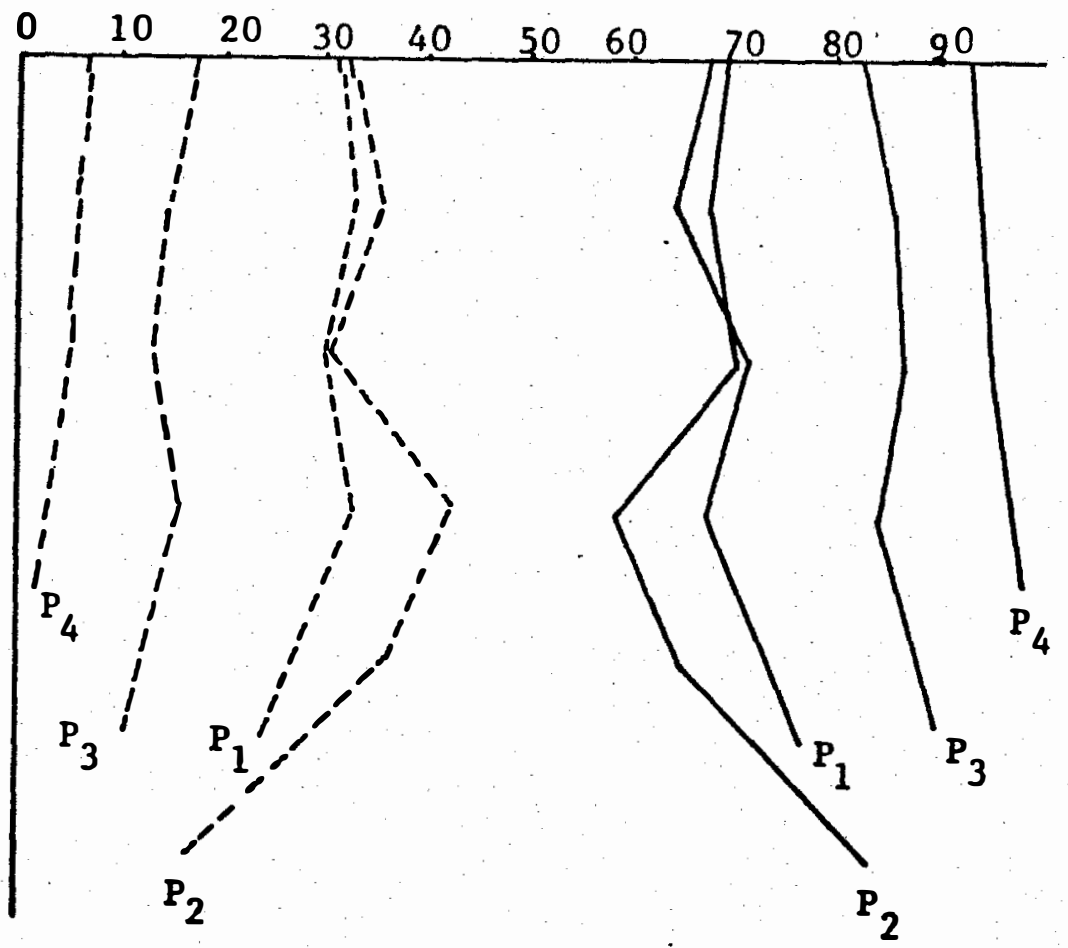

Figura 16 - Porcentagem de minerais opacos e trans parentes em profundidade dos perfis. 
Presença de descontinuidade litológica pode ser sugerida apenas para o horizonte B22, onde houve variação na re. lação zirconita/turmalina e particularmente na relação zirconita/estaurolita, aliadas à variação na curtose, sendo este horizonte de uma curva platicūrtica entre outros de curvas mesocūrticas.

\section{- 6.2.5. Perfil P4}

o perfil P4 é o mais rico em minerais pesados,com. teores variando de 10,90 a $13,68 \%$ (Tabela 15). Magnetita e ilmenita perfazem de 93,27 a $97,52 \%$, ficando o restante preenchi do por minerais transparentes representados predominantemente por zirconita em relação a estaurolita e turmalina, sendo que esta no horizonte B22 estā totalmente ausente.

Esse grande acréscimo nos teores de minerais opa cos pode estar relacionado a mudança no material de origem ou contaminação por rochas básicas. Paralelamente ao aumento de opacos, ocorre nîtida diminuição na quantidade de transparentes, que atinge valores inferiores a $4 \%$ na contagem de 300 grânulos. (Tabelas 16 e 17 ). 
Tabela 15 - Porcentagem de minerais leves e pesados da fração areia muito fina do $\mathrm{P4}$.

\begin{tabular}{ccc}
\hline Horizontes & $\%$ leve & $\%$ pesado \\
\hline Ap & 86,55 & 13,45 \\
A12 & 86,32 & 13,68 \\
B21 & 89,10 & 10,90 \\
B22 & 88,22 & 11,78 \\
\hline
\end{tabular}

Tabela 16 - Frequência dos minerais pesados da fração areia mui to fina do $P 4$.

Minerais

Horizontes

\begin{tabular}{lrrrr} 
& Ap & A12 & B21 & B22 \\
\hline Zirconita & 8 & 9 & 5 & 3 \\
Turmalina & 4 & 4 & 1 & 0 \\
Estaurolita & 2 & 3 & 7 & 1 \\
Total transparente & 14 & 16 & 13 & 4 \\
Opacos & 193 & 284 & 287 & 157 \\
No de grânulos & 207 & 300 & 300 & 161 \\
\hline
\end{tabular}


Tabela 17 - Porcentagem dos minerais pesados do P4 (os minerais transparentes somam $100 \%$ ).

\begin{tabular}{ccccc}
\hline Horizontes & 0pacos & Zi & Tu & Es \\
\hline Ap & 93,27 & 57,50 & 28,68 & 14,41 \\
B12 & 94,67 & 56,29 & 24,95 & 18,76 \\
B21 & 95,67 & 38,57 & 7,62 & 53,81 \\
B22 & 97,52 & 75,00 & 0,00 & 25,00 \\
\hline
\end{tabular}

Devido aos baixos teores de transparentes, não recomendável o estudo de relações desses minerais para investigação de uniformidade do perfil. Contudo, os dados de porcentagem de minerais leves e pesados (Tabela 15), transparentes e opacos (Tabelas 16 e 17) mostram a grande homogeneidade do perfil.

6.2.6. Considerações gerais

Os solos estudados podem ser divididos em duas ca tegorias, conforme sugerido em 6.1.5. Suportam esta divisão os resultados obtidos para porcentagens de minerais leves e pesa dos, porcentagens de minerais opacos e transparentes. Confirma a divisão proposta a Figura 16, que ilustra as porcentagens de 
minerais pesados opacos e transparentes e relação de minerais transparentes em profundidade.

Qualitativamente, os quatro perfis se assemelham, exibindo a mesma assembléia de minerais. Quantitativamente, o perfil P4 se distingue pelo teor de pesados 3 a 4 vezes superior ao dos demais. Possui, ainda, um máximo de $6 \%$ de minerais trans parentes entre os pesados, contra uma variação de 18 a $42 \%$ nos outros perfis. O perfil P4 é uniforme, enquanto os demais exi bem descontinuidades litológicas nos horizontes BI (PI), C (P2) e B22 (P3).

As duas classes de solos possuem minerais de alta estabilidade quỉmica e a presença desses minerais, aliada composição mineralógica simples, confere aos solos um caráter de elevada maturidade mineralógica.

A proveniência desses minerais estā ligada a rochas ĩgneas ācidas e intermediārias (zirconita), rochas pegmatī ticas (turmalina), rochas metamórficas de al to grau (estaurolita), sedimentos retrabalhados (zirconita, turmalina arredonda da) e rochas básicas (ilmenita e magnetita) PETTIJOHN (1949). 


\subsection{Arredondamento}

Os valores do grau e da média de arredondamento da fração areia muito fina dos perfis P1, P2, P3 e P4 (Tabela 18), mostram grau de arredondamento entre 0,45 e 0,51 para todos horizontes e, de acordo com PETTIJOHN (1957), estão classificados como grānulos arredondados.

Estes valores de arredondamento coincidem com os encontrados por SOARES (1975), para a Formação Botucatu, su gerindo para o mesmo uma deposição em ambiente desértico, eōli co.

Em relação ao arredondamento nao existe diferen ças significativas, nem entre perfis nem entre horizontes de um mesmo perfil, não confirmando nem infirmando a hipōtese de ocorrência de descontinuidade litológica sugerida pelos parâme tros estatisticos e comportamento dos minerais pesados nos per fis $P 1, P 2$ e P3. 
85.

Tabela 18 - Arredondamento dos grãos de quartzo da fração areia muito fina dos perfis.

\begin{tabular}{llllllllll}
\hline Hori- & \multicolumn{6}{c}{ Grau de arredondamento } \\
\cline { 2 - 7 } & 0,1 & 0,2 & 0,3 & 0,4 & 0,5 & 0,6 & 0,7 & 0,8 & 0,9
\end{tabular}

Médi a

Perfil 1

$\begin{array}{lrrrrrrrrrr}\text { A1 } & - & 8 & 10 & 20 & 37 & 20 & 5 & - & - & 0,47 \\ \text { B1 } & - & 4 & 8 & 23 & 50 & 12 & 3 & - & - & 0,47 \\ \text { B21 } & - & 2 & 5 & 18 & 50 & 20 & 5 & - & - & 0,50 \\ \text { B22 } & 1 & 5 & 11 & 26 & 41 & 14 & 2 & - & - & 0,45 \\ \text { B3 } & 2 & 4 & 1 & 24 & 49 & 17 & 3 & - & - & 0,48\end{array}$

Perfil 2

$\begin{array}{lllllllllll}\text { Ap } & - & 4 & 7 & 13 & 49 & 24 & 2 & 1 & - & 0,49 \\ \text { A3 } & - & 3 & 4 & 19 & 48 & 21 & 3 & 1 & 1 & 0,50\end{array}$

B21 $\quad-\quad 5 \quad 5 \quad 27 \quad 4120 \quad-\quad-\quad-\quad 0,46$

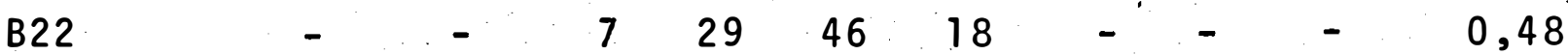

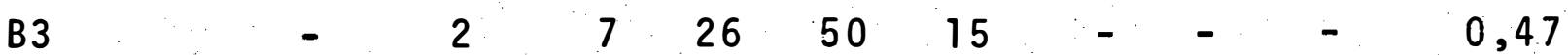

C

$\begin{array}{llllllllll}- & 1 & 12 & 40 & 33 & 13 & 1\end{array}$

Perfil 3

Ap

$24 \quad 50$

$203-1-0,50$

B 1

B21

B22

B23

$26 \quad 51$

21

0,50

$-\quad-$

20

$50 \quad 22$

$-$

0,49

$-\quad-\quad-10$

3.31

$31 \quad 46$

224

18

0,49

$-$

Perfil 4

$\begin{array}{lllllllllll}\text { Ap } & 2 & 7 & 8 & 22 & 32 & 25 & 2 & 2 & - & 0,47 \\ \text { A12 } & 1 & 3 & 14 & 20 & 41 & 17 & 2 & 2 & - & 0,47 \\ \text { B21 } & - & 1 & 2 & 26 & 46 & 23 & 2 & - & - & 0,49 \\ \text { B22 } & - & 3 & 4 & 26 & 46 & 19 & 2 & - & - & 0,48\end{array}$


86 .

7. CONGLUSOES

O estudo das caracteristicas mineralógicas e gra nulométricas confirma a hipótese de que esses parāmetros permitem distinguir solos morfologicamente semelhantes. Os solos estudados dividem-se em duas categorias: uma compreendida pelos perfis P1, P2 e P3 e outra pelo perfil P4.

A composição mineralógica da fração pesada dos quatro perfis é constituĩda de poucas espécies minerais, de ele vada maturidade química, revelando tratar-se de solos de grande maturidade mineralógica.

Os resultados de arredondamento e da composição mineralógica do residuo pesado, confirmam que os quatro solos receberam contribuição da Formação Botucatu e Serra Geral, sen- " do que no perfil P4, a presença da Formação Serra Geral é bem mais destacada. 
O solo P4 exibe grande homogeneidade granulométrica e mineralógica, enquanto os demais apresentam descontinuidades litológicas tambēm, sugeridas pelos parāmetros granulomētricos e mineralógicos. 
88.

8. LITERATURA CITADA

AGUILERA, N.H. e M.L. JACKSON, 1953. Iron oxide removal from soils and clays. Soil Sci. Soc. Am. Proc. 17: 359-364.

ALMEIDA, F.F.M., 1964.. Fundamentos geológicos do relevo paulista. In: Geologia do Estado de São Paulo. São Paulo. Instituto Geogräfico e Geológico. Bol. 167-273.

ALOISI, R.R.; N. POPPI; D. PERECIN E J.L.I. DEMATTE, 1978. ES tudos sedimentológicos de perfis de solos sob cerrado. Jaboticabal. Cientifica 6 (2): 159-164.

ALTAFIN, A., 1977. Granulometria da fração grosseira de solos desenvolvidos sobre o Arenito Bauru. Piracicaba. ESALQ, USP. 90 p. (Dissertação de Mestrado). 
ANDRADE, S.M. e P.C. SOARES, 1971. Geologia de semi-detalhe do Centro-Leste de São Paulo - Brasil. Ponta Grossa. PETROBRAS. Dep. Expl. Prod. Distr. Expl. Sul, 52 p. ilustrado.

BAHIA, B.G., 1973. Contribuição ao estudo da mineralogia de um Latossol Vermelho Amarelo-fase arenosa do Município de Iracemápolis. Piracicaba, ESALQ-USP, 75 p. (Dissertação de Mes trado):

BEAVERS, A.H., 1960. Use of X-ray spectrografic analysis for the study of soil genesis. Int. Congr. Soil Sci. Trans. $7^{\text {th }}$ (Madison, Wisconsin). 2: 1-9.

BONI, N.R., 1976. Descontinuidade litológica'em solos do Município de São Paulo, SP. Piracicaba, ESALQ-USP. 52 p. (Dis sertação de Mestrado).

BOSIO, N.J. e P.M.B. LANDIM, 1978. Um estudo sedimentológico sobre a Formação Caiuā. Curitiba. Boletim Paranaense de Geo cièncias nọ 28/29: 145-157.

BRASIL, DEPARTAMENTO NACIONAL DE PRODUÇAO MINERAL, 1979. PROJETO SAPUCAI, Estado de São Paulo, Rio de Janeiro e Minas Gerais. Relatōrio Final de geologia, por Libōrio Quirino Kaefer e outros. Brasilia DNPM/CPRM, Superintendencia Regional de São Paulo, 289 p., 4 mapas coloridos, $110 \mathrm{~cm}$. 
BREWER, R., 1964. Fabric and minerals analysis of soils. New York. Wiley and Sons. $470 \mathrm{p}$.

CADY, J.G., 1965. Petrographic microscope techniques. In: BLACK, C.A. ed. Methods of soil analysis. Madison, Series Agronomy (9): 604-631.

CAMARGO, A.P.; H.S. PINTO; O. BRUMINI; M.J. PEDRO JR.; A.A.ORTO LANI e R.R. ALFONSI, 1974. Zoneamento agrĩcola do Estado de São Paulo - Clima do Estado de São Paulo. Secretaria da Agricultura do Estado de São Paulo. Vol. 1.

CAMARgo, T. e P. VAGeler, 1937. Anālise de solos (II): 1. Anā lise Mineralógica. Boletim Técnico nọ 31 do IAC, 22 p.

CARROL, D., 1938. Recording the results of heavy mineral-analysis. Jour. Sed. Petrol. 8: 3-9.

COGEN, W.M., 1935. Some sugestions for heavy mineral investigations of sediments. J. Sed. Petrol. 5:3-8.

COMISSAO DE SOLOS, 1960. Levantamento de reconhecimento dos solos do Estado de São Paulo. Bol. Serv. Nac. Pesq. Agron., Rio de Janeiro, Centro Nacional de Ensino e Pesquisas Agronó micas, 12: 1-634. 
DEMATTE, J.L.I., 1978. Zircōnio e Titânio da fração areia de solos. Revista Brasileira de Ciência do Solo. Campinas, 2 : 74-77.

DOEGLAS, D.J., 1939. The importance of heavy mineral analys is to regional sedimentary petrology. Rept. Comm. Sedimenta tion, National Research Council: 102-121.

DUARTE, U., 1980. Geologia ambiental da area de São Pedro-SPVetor Aguas Subterrāneas. São Paulo. Instituto de Geociēncias da Universidade de São Paulo, 73 p. (Tese de Doutora mento).

FOLK, R.L. e W.C. WARD, 1957. Brazos river bar:A study in the significance of grain size parameters. J.Sed. Petr., 27:327.

FREIRE, 0.; J. GIMENEZ; J.E. PESSOTTI. e E. CARRARO, 1978. SOlos da Bacia do Broa. São Carlos. Universidade Federal de São Carlos. $125 \mathrm{p}$.

GALHEGO, H.R., 1977. Mineralogia de solos de uma topossequência da região de contato do Planalto 0cidental com as cues tas basāiticas do Município de Botucatu, S.P. Píracicaba. ESALQ-USP. 62 p. (Dissertação de Mestrado). 
HASEMAN, J.F. e C.E. MARSHALL, 1945. The use of heavy-minerals in studies of the origin and development of soils. Mo. Agr. Exp. Sta. Res. Bul1. 387.75 p.

HENDRICK, J. e G. NE(ULANDS, 1923. The value of mineralogical examination in determining soil types; with a method of exami nation and a comparison of certain english and scottish soils. Jour. Agr. Sci. 13: 1-17.

JACKSON, M.L., 1956. Chemical analysis. Advanced Course. Pub. by the Author. Dept. fo Soils, Univ. of Wisconsin, Madison, Wisconsin, U.S.A. 991 p. (mimeo.).

JEFFRIES, C.D., 1937. The mineralogical composition of the very fine sands of some Pennsylvania soils. Soil Sci. 43: 357366 .

JEFFRIES, C.D. e M.L. JACKSON, 1949. Mineralogical analys is of soils. Soill Sci. 68: 57-73.

KILMER, U.J. e J. ALEXANDER, 1949. Method of makiey mechanical analysis of soils. Soil Sci. 68: 15-26.

KRUMBEIN, W.C. e F.J. PETTIJOHN, 1938. Manual of sedimentary petrography. Appleton-Century-Crofts, Inc. New York, U.S.A. $549 \mathrm{p}$. 
KRUMBEIN, W.C., 1941. The effects of abrasion on the size sha pe and roudness of rock fragments. J. Ged. $\underline{49}$ (5): 449-482.

KRUMBEIN, W.C. e L.L. SLOSS, 1969. Estratigrafia y sedimentaciōn. UTEHA, Mēxico, 2ạ ed. 778 p. Uniōn Tipogrāfica Editorial Hispano-Americana UTEHA.

KRYNINE, P.D., 1946. The tourmaline group in sediments. J. Geol. 54 (2): 65-87.

KÜPPER, R. de B., 1978. Mineralogia e granulometria de dois Latossolos Vermelho Amarelo-orto da Serra da Mantiqueira,SP. Piracicba, ESALQ-USP. 83 p. (Dissertação de Mestrado).

LOBO, A.E.M., 1971. Descontinuidade litológica de alguns solos da região de Piracicaba. Piracicaba, ESALQ-USP. 65 p. (Dissertação de Mestrado).

MARCONI, A., 1969. Contribuição ao estudo da mineralogia de solos do Município de Piracicaba. Piracicaba, ESALQ-USP. $101 \mathrm{p}$. (Tese de Doutoramento).

MARCONI, A.; I.0. ABRAHAO e I.R. NOGUEIRA, 1970. Efeito de operadores, dia de observação e tamanho de amostra e de grānulos na determinação do arredondamento da fração areia de solos. Anais da ESALQ/USP, 27: 205-209. 
MARCONI, A. e 1.0. ABRAHAO, 1977. Mineralogia e granulometria de três latossolos da região do Médio Rio São Francisco, BA. Anais da ESALQ/USP. 33 (39): 415-428.

MARINS, M. de A., 1975. Ecologia da alga Melaziva italica (Ehr.) Kutz. Represa do Lobo. Estado de São Paulo. Universidade de São Paulo. 144 p. (Tese de Doutoramento).

MARSHALL, C.E. e C.D. JEFFRIES, 1945. Mineralogical methods in soil research. Soil Sci. Soc. Am. Proc. 10: 347-405.

MILNER, H.B., 1962. Sedimentary petrography. George selen and Unwin Ltd. London, England. 4a ed. 20 vol. 1358 p.

PARAguassa, A., 1970/1971. Sedimentos aquosos da Formação Bọ tucatu. Curitiba. Bol. Paranaense de Geociências nọ 28/29: $193-210$.

PETTIJOHN, F.J., 1949. Sedimentary rocks. New York. Harper. $526 \mathrm{p}$.

PETTIJOHN, F.J., 1957. Sedimentary rocks. Harper and Brothen. New York, USA. 2? ed. $718 \mathrm{p}$.

RODRIGUES, E.M., 1979. Granulometria e mineralogia de Latos sol Roxo do Município de Piracicaba-SP. Piracicaba, ESALQ-USP 63 p. (Dissertação de Mestrado). 
ROSENFELD, M.A. e J.C. GRIFFITHS, 1953. An experimental test of visual comparison technique in estimating two-dimensional sphericity and roundness of quartz grains. Am. Jour. Sci. $251: 553-585$.

RUBEY, W.W., 1933. The size distribution of heavy minerals wi thin a water-laid sandstone. J. Sed. Petr. 3: 3-29.

SINDOWSKI, F.K.H., 1949. Results and problems of heavy-mine rals analysis in Germany. J. Sed. Petr. 19: 3-25.

SOARES, P.C., 1972. Arenitos Botucatu e Pirambóia no Estado de São Paulo. XXVI Cong. Bras. Geol. Boletim l, 250-251, São Pau1o.

SOARES, P.C.,. 1975. Divisão estratigräfica do Mesozóico no Es tado de São Paulo. R. Bras. Geoc. São Paulo 5:23.

Suguio, K., 1973. Introdução a sedimentologia. São Paulo. Ed - gard BIdcher, Ed. USP, 317 p.

SUGUIO, K.; M. COIMBRA e L.R. GUARDADO, 1974. Correlação sedi mentológica de Arenitos da Bacia do Paranā. Bol. Inst. Geoc. USP. São Pau10, 5: 85-116. 
SUGuIo, K.; A.M. COIMBRA, 1976. Estudo sedimentolögico das "Bandas Onduladas" de solos da Formação Bauru na Area Balisada pelas Cidades de Osvaldo Cruz - Rancharia e Tupã, Estado de São Paulo. Boletim I.G. Instituto de Geociências,USP. São Paulo, 7: 27-38.

VILLELA, S.M. e A. MATTOS, 1975. Hidrologia aplicada. São Paü10. McGraw-Hill. 245 p.

WERNICK, E.; A.C. ARTUR e R.R. CORDEL, 1972. Comparação entre a forma de grãos de quartzo dos arenitos Botucatu e Bauru. Notĩcia Geomorfológica. Campinas, 12: 83-91.

WINKELJOHANN, J.M.S., 1975. Descontinuidade litológica em per fis de solos da Série Guamium (Latossolo Vermelho Amarelo-or to). Piracicaba, ESALQ-USP. (Dissertação de Mestrado). 